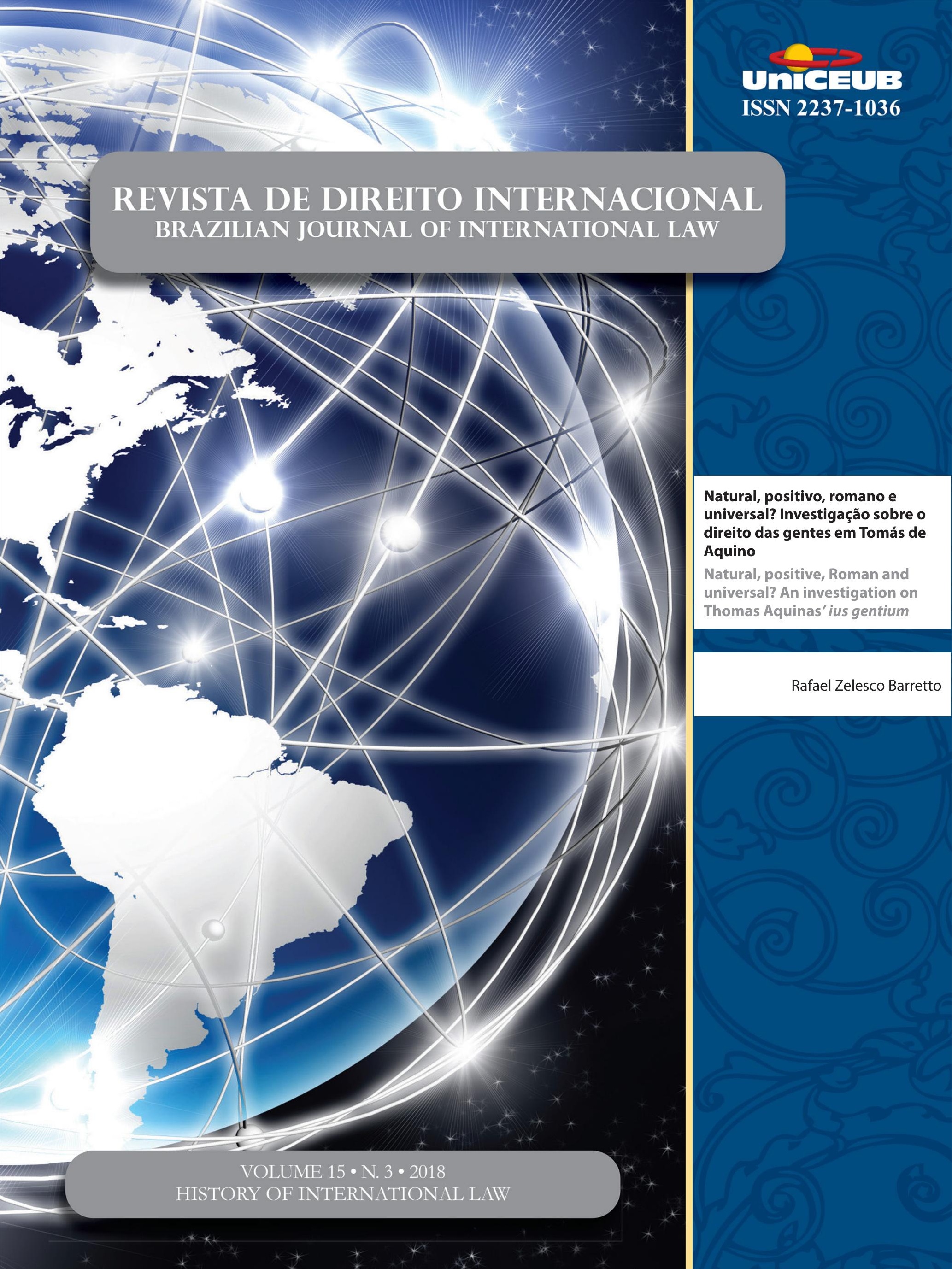




\section{Sumário}

I. Dossiê Especial: History of International Law ...................................1

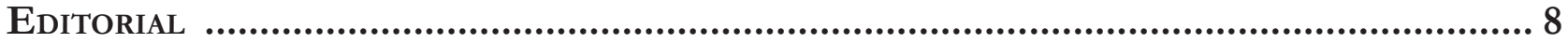

What does it mean to apply history in international law studies? ....................................................... 8

Arthur Roberto Capella Giannattasio

SuR LA NATURE DU Droit ISLAMIQUe............................................................................14

Hocine Benkheira

Islamic Shari’a Law, History and Modernity: Some Reflections .................................25 Suleiman A. Mourad

The (Un)practical Secularization Process: International Law and Religion as So-

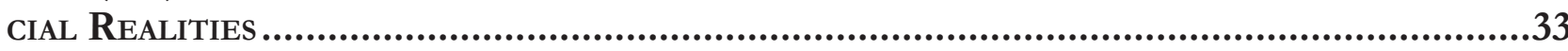

Douglas de Castro

BRAZILIAN LITERATURE ON INTERNATIONAL LAW DURING THE EMPIRE REGIME. OR THE DIFFUSION OF INTERNATIONAL LAW IN THE PERIPHERIES THROUGH APPROPRIATION AND ADAPTATION.

Airton Ribeiro da Silva Júnior

Natural, POSitivo, romano E Universal? INVESTigaÇão SObre O Direito das GENTES EM

Tomás de Aquino

Rafael Zelesco Barretto

II. Artigos sobre outros temas

VINCULAÇÃO DOS DIREITOS ECONÔMICOS, SOCIAIS E CULTURAIS: UMA DISCUSSÃO DO DESENVOLVImento humano com base no conceito de Amartya Sen sobre o mínimo existencial.....99

Natalia Mascarenhas Simões Bentes e Yasmim Salgado Santa Brígida

A NOVA LeI de MigraÇão E A PROTEÇão CONFERIDA AO APÁtrida: ALINHAMENTO BRASILEIRO AO PADRÃO INTERNACIONAL DE DIREITOS HUMANOS

Pedro Henrique de Faria Barbosa e Sylvio Loreto

E se o Supremo Tribunal Federal (STF) restabelecer a vigência da Convenção n. 158 
da Organização Internacional do Trabalho (OIT) na ordem Jurídica brasileira? SoBRE UMA POSSÍVEL REVIRAVOLTA, PELA VIA DO DIREITO INTERNACIONAL, DAS LEIS TRABALHISTAS BRASILEIRAS 138

Daniel Damasio Borges

JULGADOS DA CORTE INTERAMERICANA SOBRE CASOS BRASILEIROS E POLÍTICAS PÚBLICAS: REFLEXÕES ACERCA DE POSSÍVEIS INFLUIÇÕES 165

Rafael Osvaldo Machado Moura

CREATING BRIDGES BETWEEN INTERNATIONAL RELATIONS THEORY AND INTERNATIONAL HUMAN RIGHTS LAW: CONSTRUCTIVISM AND THE ROLE OF BRAZIL IN THE INTER-AMERICAN SYSTEM OF HUMAN RIGHTS 179

Ismael Francisco de Souza, Luciana Rocha Leme e Erick da Luz Scherf

Justiça de transição na Argentina e o Sistema Interamericano de Direitos Humanos: uMa ANÁlise do CASo Luis Muiña (“REgRa 2x1”) 199

Emilio Peluso Neder Meyer e Jessica Holl

A legalidade e legitimidade da INTERVEnÇão humanitÁria: UMA MEDIDA AINDA NECESSÁRIa.219 Natália Caye Batalha Boeira

O Acordo de Escazú E o ACESSo À INFORMaÇão AMbiental no Brasil. 252 Érica Bezerra Queiroz Ribeiro e Bruno Amaral Machado

Dos POVOS NATIVOS AO SURGIMENTO DOS MOVIMENTOS SOCIAIS: INFLUÊNCIAS DOS DISCURSOS JURÍDICOS, RELIGIOSOS E MÉDICOS PARA A CONSTRUÇÃO DO CONCEITO DE HOMOSSEXUALIDADE NO BRASIL .267 Bruno Rafael Silva Nogueira Barbosa e Robson Antão de Medeiros

Aspectos Jurídicos da PARTicipaÇão dA UNião Europeia NA OMC: COMPREENDENdo SUTILEZAS DE UM DELICADO ENLACE. 291

Camilla Capucio

Path to judicial activism? The use of "Relevant rules of international law" by the WTO Appellate Body

Mariana Clara de Andrade

LEVEZA E PESO NA MEDIAÇÃO COMERCIAL INTERNACIONAL: O CONTEÚDO JURÍDICO DO ACORDO CORPORATIVO MEDIADO E SUA INCORPORAÇÃo PELO DiREITO BRASILEIRO .324 Henrique Lenon Farias Guedes 
JURISDIÇÃO INTERNACIONAL E AS DIFICULDADES DE EXECUÇÃO DE SENTENÇAS INTERNACIONAIS NO BRASIL

Nevitton Vieira Souza

O DEVER DE COOPERAÇÃo NOS CONTRATOS DE VENDA INTERNACIONAL DE MERCADORIAS: PRESSUPOSTOS TEÓRICOS E REPERCUSSÕES PRÁTICAS DA CLÁUSULA GERAL DA BOA-FÉ OBJETIVA PARA A APLICAÇÃo DA CISG .358

Angelo Gamba Prata de Carvalho

A DiMENSÃo JURÍdiCA DO IMPERIALISMO NA (DES)ORDEM GLOBAL CAPITALISTA: UMA ANÁLISE COM BASE NA CRÍTICA MARXISTA AO DIREITO INTERNACIONAL E ÀS RELAÇÕES POLÍTICO-ECONÔMICAS DE DOMINAÇÃO E DEPENDÊNCIA.

Thomaz Delgado De David, Maria Beatriz Oliveira da Silva e Rosane Beatris Mariano da Rocha Barcellos Terra

A participaÇão de Brasil e Estados Unidos na formulação das regras multilaterais do

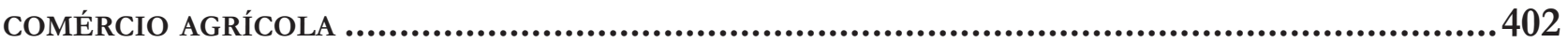

Vera Thorstensen, Vivian Daniele Rocha Gabriel e Alebe Linhares Mesquita

A galáxia lex e a construÇão de um Sistema jurídico transnacional ........................ 441

Eugênia Cristina Nilsen Ribeiro Barza e Jéssyka Maria Nunes Galvão

Has the Ability of Truth Commissions to Recommend Amnesty Been Effective in Enhancing Perpetrator Cooperation? 453 Jeremy Sarkin

A CONCEPTUAL PAPER ON THE POLICY-FRAMEWORK THAT MIRRORS THE DYNAMIC LINK BETWEEN Human Security, Social Protection and Safety Nets, and Food and Nutritional Security: The Case of the "Gulayan sa Paaralan Program", the Philippines.... 478 Renato Lagapa Base

INCENTIVISING SMALLHOLDER FARMER LIVELIHOODS AND CONSTRUCTING FOOD SECURITY THROUGH HOME-GROWN SCHOOL FEEDING: EVIDENCE FROM NORTHERN GHANA .491

Clement Mensah

Policy COHERENCE In THE IMPLEMENTATION OF THE 2030 AgENDA FOR SUSTAINABLE DEVELOpment: the Brazilian School Feeding Programme Case Study .506 Mariana Werlang Girardi 


\title{
Natural, positivo, romano e universal? Investigação sobre o direito das gentes em Tomás de Aquino*
}

\author{
Natural, positive, Roman and universal? \\ An investigation on Thomas Aquinas' ius \\ gentium
}

Rafael Zelesco Barretto**

\section{Resumo}

O artigo busca sintetizar o pensamento de Tomás de Aquino sobre o direito das gentes. Trata-se de uma instância intermediária entre os direitos natural e positivo, determinada pelos institutos repetidos entre os diversos povos. A hipótese de trabalho, que se pensa haver comprovado no texto, refere-se ao fato de que o direito das gentes tomista não é mera herança do direito romano, adquirindo teor de universalidade e generalidade que marca toda a teoria jurídica do Aquinate. O método seguido foi a contextualização dos trechos relevantes das obras de Tomás de Aquino. Consideraram-se, para este artigo, as distintas influências que deixaram vestígios em suas passagens sobre o ius gentium. Estas foram lidas, em apartados sucessivos deste trabalho: à luz do problema específico ao qual respondiam nos escritos de Tomás; em um enfoque sistemático com a lógica interna da Suma Teológica; à luz dos jurisconsultos romanos citados pelo Aquinate; e com referência ao raciocínio jurídico aristotélico, sobretudo relacionado à proporcionalidade. As conclusões provisórias são, em seguida, comparadas com a interpretação de outros historiadores do pensamento jusinternacionalista a respeito do Aquinate, o que permitiu ressaltar certas nuances da postura do teólogo medieval.

Palavras-chave: História do direito internacional. Ius gentium. Tomás de Aquino. Direito natural. Direito romano.

* Recebido em: 30/09/2018 Aprovado em: 11/01/2019

** Doutor em Direito Internacional pela Universidade do Estado do Rio de Janeiro (UERJ). Professor adjunto do Programa de Pós Graduação em Estudos Marítimos da Escola de Guerra Naval. E-mail: rafaelzb2010@gmail.com

\section{Abstract}

The purpose of this essay is to synthetize the thought of Thomas Aquinas on the law of peoples. Ius gentium is an intermediary stance between natural and positive laws, and is to be determined by the institutes which are common between different peoples. The working hypothesis, which is thought to have been confirmed by this article, is that thomist ius gentium is more than just an inheritance of Roman law. It is a coherent part of Aquinas' juridical theory, keeping both its typical generality and universality. This essay follows a contextualized reading of relevant texts of Aquinas. It seeks to take account of the different influences which can be seen in his writings 
on ius gentium. The different sections of this work first consider those primary sources as answers to specific problems Aquinas was answering in his writings, then as part of a coherent system bound by the inherent logic of the Summa Theologiae, then in the light of the roman jurists mentioned by Aquinas, and finally referring to Aristotle's juridical thought, and specially to his notion of proportionality. Provisonal conclusions are then compared to the positions of other International Law History scholars, allowing to highlight certain features of the reasoning of Thomas Aquinas.

Keywords: International Law History. Ius gentium. Thomas Aquinas. Natural Law. Roman Law.

\section{INTRODUÇão}

O propósito deste trabalho é sintetizar o pensamento de Tomás de Aquino sobre o ius gentium. Trata-se de um dos pontos mais controversos na parte jurídica de sua monumental Suma Teologica1. No século XIX, um dos grandes proponentes da aplicação do rigor metodológico científico ao direito internacional, Carl von Kaltenborn, qualificou a contribuição de Tomás de Aquino como pouco clara, incompreensível e repleta de saltos lógicos e contradições ${ }^{2}$. Admite-se que a construção do mestre de Roccasecca no tema do ius gentium não apresenta a clareza e o rigor encontrados em outras partes da Suma. Porém, em sua defesa, sustenta-se que o direito das gentes tomista ${ }^{3}$ é parte indissociável de sua teoria jurídica, a qual, por seu turno, integra sua Antropologia, sendo elaborada por meio de certas noções filosóficas que devem ser consideradas. Ou seja, a ideia tomista de ius gentium somente poderá ser corretamente compreendida caso lida a partir dos pressupostos epistemológicos e metodológicos empregados pelo monge dominicano.

1 ESTÉBANEZ, Emilio G. La virtud de la justicia. Introducción a las cuestiones 57 a 60. In: AQUINO, Santo Tomás de. Suma de Teología, tomo III. Madri: Biblioteca de Autores Cristianos, 1990, pag. 460 et seq.

2 Apud KOSKENNIEMI, Martti. A History of International Law Histories. In: FASSBENDER, Bardo; PETERS, Anne (orgs.). The Oxford Handbook of the History of International Law. Oxford: Oxford University Press, 2012, pag. 954.

3 Com a difusão dos estudos sobre Tomás de Aquino, a palavra "tomista" passou a designar a corrente de pensadores que se inspira nos textos do Aquinate. Neste trabalho, contudo, utilizar-se-á o termo sempre em seu sentido original, referindo-se unicamente a Santo Tomás.
Este artigo é uma tentativa neste sentido. Procura-se o direito das gentes de Tomás de Aquino na forma em que este autor o teria em mente. Para isso, empregou-se a análise textual das obras em que o ius gentium é mencionado, com particular respeito à relação de cada passagem relevante com o contexto geral da obra. Isto porque, mesmo que apresente uma estrutura esquemática que favoreça sua citação quase que a modo dos artigos de uma lei, a Suma Teológica não constitui uma coleção de brocardos, e sim uma compilação coerente, embora necessariamente incompleta, dos principais temas tratados pela Teologia. Portanto, embora sempre possa ser corrigida por investigações ulteriores, a Suma se pretende um esmaecido reflexo de uma verdade universal: o conteúdo pode não estar certo, mas independe de considerações de tempo e lugar - afinal, seu tema é ninguém menos que Deus, que transcende tais fatores.

O direito das gentes em Tomás de Aquino é um tema instigante para o historiador do Direito Internacional. Por um lado, a contribuição do Aquinate parece modesta: esse ramo do direito ocupa pouquíssimos artigos de sua obra magna e é apenas tangenciado em alguns de seus outros escritos. Além disso, é descrito com grande fidelidade aos velhos jurisconsultos romanos, abundantemente citados, e de quem o Doutor Angélico empresta o vocabulário, as definições e o roteiro geral de sua argumentação na matéria. À primeira vista, o estudo tomista parece pouco mais que uma atualização medieval (portanto, desatualizada no presente) das elucubrações da Antiguidade latina.

Contudo, é patente que tal não teria sido a intenção de Tomás de Aquino. Ele não era jurista e nem estava envolvido com alguma controvérsia de direito das gentes à época da elaboração da Suma. Seu interesse pelo conceito romano do ius gentium era absolutamente instrumental: este lhe servia para completar o estudo do ius, o qual desenvolvia a virtude cristã da Justiça. Como se vê, o teólogo se movia no âmbito do universalismo moral cristão. Nessa perspectiva, qualquer homem, em qualquer tempo e lugar, pode e deve ser "justo" tal qual descrito na Suma Teológica. Da mesma forma, o direito estudado nessa obra é uma ideia geral, suscetível de aplicação por qualquer sociedade humana. Como enquadrar, então, o ius gentium, que é ramo desse direito? Ele, também, constitui um modelo capaz de aplicação universal?

A hipótese deste trabalho é que o ius gentium tomista 
situa-se coerentemente em sua teoria jurídica e, portanto, se aplica, ao menos na intenção de seu autor, às comunidades humanas em geral, abstraindo das realidades romana e medieval. Em outras palavras, que o direito das gentes é parte cardeal, e não acessória, do raciocínio do autor da Suma sobre o fenômeno jurídico.

Desenvolver essa hipótese é de interesse para compreender a transição entre o ius gentium romano — individual, privatista, nacional na aplicação e alienígena no conteúdo - e o Direito Internacional moderno - estatal, público e de aplicação universal. Respondendo-se afirmativamente à pergunta de pesquisa, ter-se-á um indício de transição entre as concepções romana e contemporânea das relações (jurídicas) internacionais. Caso a resposta seja negativa, será necessário buscar em outro momento o início desta transição.

Para comprovar a hipótese, emprega-se neste trabalho um método de leitura contextual das passagens relevantes do Aquinate. Serão examinadas por perspectivas cada vez mais amplas, que possam replicar, adequadamente, o ponto de partida e as intenções prováveis do autor da Suma ao tratar do ius gentium. Os trechos que estudam o direito das gentes serão lidos, sucessivamente, nos marcos: (1) do vocabulário jurídico-moral tomista, cujos significados diferem do entendimento predominante na atualidade; (2) do próprio artigo em que foram escritos, para compreender a discussão subjacente; (3) da Suma Teológica como um todo, respeitando sua coerência interna; (4) das fontes romanas citadas pelo Aquinate; (5) do raciocínio jurídico aristotélico, especialmente da ideia de proporcionalidade; e (6) dos posicionamentos de representantes destacados da historiografia jusinternacionalista, a fim de compará-los com as conclusões do presente artigo.

O trabalho foi desenvolvido em seis partes, que correspondem aos contextos interpretativos citados acima. Assim, a seção 2 traz um resumo dos conceitos mais importantes da teoria jurídico-moral de Tomás de Aquino, ainda sem mencionar o direito das gentes. A seção 3 mapeia as citações do autor acerca do ius gentium, identificando as discussões específicas nas quais o tema vem à tona. A seção 4 examina a coerência entre os diferentes momentos em que o ius gentium é estudado pelo Aquinate, sobretudo na Suma Teológica, com um apartado para o Tratado da Lei e outro para o Tratado da Justiça. A seção 5 busca identificar qual a concepção de ius gentium encontrada pelo teólogo medieval entre os juristas romanos que citou. A seção 6 verifica a compatibilidade entre o direito das gentes tomista e o marco filosófico-jurídico aristotélico, do qual Tomás se fez herdeiro. A seção 7 debate posicionamentos de outros autores sobre o direito das gentes em Tomás de Aquino.

Para essa última seção, na qual as conclusões parciais alcançadas serão estudadas pela lente do contraditório, foram selecionados os trabalhos de Santiago Ramírez ${ }^{4}$, Peter Haggenmacher ${ }^{5}$ e Michel Villey ${ }^{6}$, que representam abordagens atuais e diferentes sobre o ius gentium tomista. O primeiro autor traz a perspectiva dos estudos tomistas, examinando a relação do direito das gentes com o direito natural, e algumas questões morais, como sua relação com a escravidão. O segundo, que é historiador do Direito Internacional, abordou a consistência e unidade conceitual do direito das gentes. O último, estudioso da Filosofia do Direito em perspectiva histórica, deteve-se especialmente no método do direito das gentes, em relação com a clássica "arte do direito" de origem romana.

\section{Precisões conceituais: o direito em Tomás de Aquino}

Antes de ingressar na análise do direito das gentes, é necessário traçar um breve panorama dos principais conceitos jurídicos esgrimidos pelo monge dominicano ${ }^{7}$. Note-se bem que Tomás de Aquino é teólogo, não jurista, e somente trata do Direito quando levado a tal

4 Santiago María Ramírez y Ruiz de Dulanto (1891-1967), teólogo espanhol tomista, autor de diversas obras em teologia, metafísica e filosofia política. Foi um dos responsáveis pela primeira edição da grande tradução espanhola da Suma Teológica pela Biblioteca de Autores Cristianos.

5 Peter Haggenmacher (1944- ) foi professor no Graduate Institute of International Studies de Genebra. Autor de uma monumental tese doutoral sobre Hugo Grócio, foi o pioneiro na aplicação do método da historiografia dos conceitos à história do direito internacional.

6 Michel Villey (1914-1988), jusfilósofo e historiador do direito francês, foi responsável por resgatar a teoria jurídica aristotélicotomista na França, influenciando também em sua redescoberta na América Latina.

7 Para estudos mais completos sobre a doutrina jurídica de Tomás de Aquino, cf. VILLEY, Michel. A formação do pensamento jurídico moderno. São Paulo: Martins Fontes, 2005, pags. 131-198; FINNIS, John. Aquinas. Moral, Political, and Legal Theory. Oxford: Oxford University Press, 1998 (reimpr. 2004), pags. 132-215; BASTIT, Michel. Nascimento da lei moderna: o pensamento da lei de Santo Tomás a Suarez. São Paulo: Martins Fontes, 2010, pags. 3-191. 
pela Teologia, no caso da Suma Teológica ${ }^{8}$, ou pela Filosofia Moral, quando comenta a Ética a Nicômaco de Aristóteles ${ }^{10}$. Mais especificamente, na Suma, quando ele se interessa pelos fatores externos que podem influenciar a conduta humana, estuda a graça divina, as tentações do demônio, e a Lei - de Deus, da natureza e dos homens. Adiante, quando passa a tratar das virtudes, isto é, dos bons hábitos que conduzirão a pessoa à bem-aventurança eterna, ele se detém sobre a Justiça. É por isso que o que se poderia chamar de "teoria jurídica" de Aquino está dividida entre duas partes separadas de sua obra magna, respectivamente, o Tratado da Lei ${ }^{11} \mathrm{e}$ o Tratado da Justiça ${ }^{12}$.

Em primeiro lugar, observa-se que o conceito de "direito" é identificado pelo Aquinate com o objeto da justiça ${ }^{13}$. Assim, o direito é o meio sobre o qual se exerce a ação demandada pela virtude da justiça. Esta é definida, de acordo com a tradição aristotélica, como "dar a cada um o seu". É uma virtude importante, por ser a única a referir-se, imediatamente, à outra pessoa: enquanto as demais virtudes se dirigem, primeiramente, ao aperfeiçoamento individual, e, somente depois, de modo reflexo, ao bem do restante da comunidade, a virtude da justiça exerce-se sobre as ações exteriores, buscando, em primeiro lugar, corrigir as relações interpessoais, para, posteriormente, de maneira indireta, contribuir para a melhoria do próprio agente enquanto pessoa. Por isso, ao erigir o "outro" como destinatário primeiro da ação virtuosa, a justiça é essencialmente igualitária.

A justiça é o bom hábito que ordena a vontade, le-

8 AQUINO, Tomás de. Suma teológica, 9 vols. Tradução ao português pela equipe da ed. Loyola. São Paulo: Loyola, 2005.

9 O modo tradicional de referenciar a Suma Teológica (ST) distingue as quatro partes em I (Prima pars), I-II (Prima Secundae ou "Primeira da Segunda"), II-II (Secunda Secundae, "Segunda da segunda") e III (Tertia pars). Note-se que "I-II" reflete o uso do caso genitivo no latim, e corresponde à primeira seção da segunda parte. Cada parte se divide em questões, citadas por " $q$. ", que correspondem a um tema. Por sua vez, subdividem-se em artigos, ou " $a$.", sempre no formato de uma pergunta, cuja resposta aparente, que será refutada, é indicada logo a seguir. No artigo, enfim, distinguem-se: as objeções ("obj."), que sustentam a tese combatida; a primeira refutação destas ("sed contra"), onde o autor busca apoio em outras fontes para sua posição; o corpo da resposta (“corpus"), onde o autor argumenta pela sua tese; e as respostas a cada objeção ("ad 1", "ad 2" etc.).

10 AQUINO, Santo Tomás de. Da Justiça. (Título original: "Sententia libri Ethicorum, Liber 5".) Tradução de Tiago Tondinelli. Campinas: Vide Editorial, 2012.

11 ST I-II q. 90-108.

12 ST II-II q. 57-79.

13 ST II-II q. 57 a. 1. vando-a a manter o respeito pelas coisas alheias - corpóreas ou não. Note-se que a marca distintiva da justiça, que é o manifestar-se na conduta externa no âmbito de uma relação interpessoal visando ao bem da outra pessoa, a situa e, ao mesmo tempo, a singulariza em relação ao que hoje se conhece como moral. Enquanto esse termo designa uma instância de julgamento das ações humanas que toma por critério o necessário para uma vida boa, a justiça, ainda que necessária para o aperfeiçoamento moral, compõe uma instância de julgamento diferente, pois avalia as condutas com base apenas no seu resultado, e não na intenção do agente. É uma virtude extremamente objetiva. O objeto desta são as coisas - mais especificamente, as coisas que devem ser entregues ao outro. Como o direito é o objeto da justiça, tem-se que o direito, no esquema tomista, é uma coisa, uma res, externa ao homem. O direito é, sobretudo, o que é devido a outrem.

Esse direito pode ser determinado com atenção a duas grandes fontes: a natureza das coisas e a convenção humana. A natureza das coisas significa o modo como elas são: em primeiro lugar, os partícipes da relação jurídica são essencialmente iguais em valor entre si. Em segundo lugar, o objeto em permuta possui determinado valor em determinado tempo e lugar, e tal valor deve ser correspondido durante a transação. Essa exigência radical de igualdade em todo tipo de relação interpessoal envolvendo bens é o direito natural. Por ser demasiado genérico, impõe-se sua complementação, pela sociedade, com atenção às circunstâncias pertinentes: será o direito positivo, ou "posto" pela sociedade. Em síntese, aceitando-se a definição tomista de que o direito é a coisa a ser entregue ao outro, tem-se que direito natural e direito positivo são recortes sucessivos da realidade, que buscam delimitar, com precisão crescente, qual a substância e a medida desta "coisa".

Toda a temática da determinação do direito está enquadrada na ideia de lei. A lei é, para Tomás de Aquino, a regra e medida dos atos. Ele distingue entre a lei divina, cujo estudo não interessa aqui, a lei natural e a lei humana. Essa última é promulgada pelo príncipe, orientando a comunidade rumo ao bem comum. Já aquela é o reflexo das regularidades que podem ser percebidas na natureza, incluindo aí o modo de ser do homem. Importa ressaltar que a lei natural não alcança somente o que hoje se conhece por campo jurídico. Como o próprio homem está na natureza, a lei natural o abrange inteiramente: há preceitos de moral, cortesia, política etc. 
que também são exigências da lei natural.

Essa precisão é importante para consolidar uma distinção fundamental, porém, pouco comentada, na teoria jurídica do autor da Suma: direito natural e lei natural não se confundem, sendo esta a moldura teórica onde aquele se determina. A lei natural reconhece as regularidades que há no mundo e as formula como princípios para a ação humana. O direito natural, por seu turno, somente aparece diante de um caso concreto, uma relação interpessoal envolvendo bens, no qual ele orientará a solução para a manutenção da igualdade fundamental de valor. Em síntese: a lei natural é imutável, embora a operação de sua descoberta e formulação nunca termine. Já o direito natural é mutável, quase a modo de proporção, variando na medida das circunstâncias de cada relação litigiosa, buscando manter sempre a igualdade presente na natureza.

O esquema jurídico tomista, portanto, não se baseia em leis naturais deduzidas da natureza ou da religião, que devem ser aplicadas de modo rígido por sobre as leis positivas. Trata-se, antes, da compreensão do direito enquanto objeto da justiça, tendo por tarefa precípua manter a igualdade nas trocas, obedecendo a padrões naturais e convencionais.

\section{3. $O$ ius Gentium EM dUAs Passagens da Suma E UMA DA ÉTICA}

Esta seção inicia o estudo específico sobre o tema central do trabalho, mapeando as menções mais importantes ao direito das gentes na obra de Tomás de Aquino. Selecionaram-se duas passagens da Suma Teológica uma do Tratado da Lei e outra do Tratado da Justiça - e um trecho do Comentário à Ética a Nicômaco.

Examinando especificamente o direito das gentes, parece difícil entender qual o seu lugar no esquema tomista das fontes do direito: pertence ao direito natural, ao direito positivo ou integra uma terceira categoria? A dúvida, originada por trechos díspares da Suma Teológica, principia, na leitura do Tratado da Lei, que integra a metade inicial da segunda parte. Ali, ele parece ser de direito positivo:

É da razão da lei humana que seja derivada da lei da natureza, como se evidencia do que acima foi dito. $\mathrm{E}$, de acordo com isso, divide-se o direito positivo em direito das gentes e direito civil, segundo os dois modos pelos quais algo deriva da lei da natureza, como foi dito acima. Com efeito, pertencem ao direito das gentes aquelas coisas que derivam da lei da natureza como as conclusões dos princípios, como as compras justas, as vendas, e outras coisas semelhantes, sem as quais os homens não podem conviver uns com os outros, o que é da lei da natureza, porque o homem é naturalmente animal social. $^{14}$

Como se vê, embora inicie afirmando que o direito das gentes faz parte do direito positivo, Tomás assevera que o único motivo para tal classificação é o fato de derivar da lei natural: é possível considerar, por contraste, que todo o direito derivado desta é direito positivo. Quando se ocupa exclusivamente do direito das gentes, porém, ele volta a aproximá-lo da lei natural, ao dizer que deriva desta de modo quase imediato, como as conclusões se extraem dos princípios - ao contrário do direito positivo, que necessita da intervenção determinante da vontade humana. Alguns parágrafos depois, sua posição é esclarecida:

Deve-se dizer que o direito das gentes é de algum
modo natural ao homem, segundo [o homem]
é racional, enquanto [aquele] deriva da lei natural
a modo de [uma] conclusão, que não é muito
afastada dos princípios. Donde, facilmente, em tal
os homens consentiram. Distingue-se, porém, da lei
natural, maximamente enquanto é comum a todos
os animais. ${ }^{15}$

A grande diferença entre lei natural e direito das gentes parece ser, no âmbito de aplicação: a primeira se aplica, também, aos animais, o segundo não. É preciso considerar que a obediência dos irracionais a seus instintos somente pode ser descrita impropriamente como decorrendo de uma lei, como já se viu. Então, se a diferença for apenas essa, não há uma grande separação. Se, na primeira leitura do Tratado da Lei, o ius gentium é positivo, o iter do raciocínio tomista parece inclinar-se para classificá-lo sob a rubrica do direito natural.

Já o Tratado da Justiça, que aborda essa virtude na segunda metade da segunda parte da Suma, o direito das gentes parece assumir a posição oposta:

Em sentido contrário, Isidoro declara: 'O direito ou é natural ou civil ou das gentes'. Assim, o direito das gentes é distinto do direito natural. [...] Como se disse, o direito ou o justo natural é o que, por natureza, é ajustado ou proporcional a outrem. Ora, isso se pode dar de duas maneiras: primeiro, segundo a consideração absoluta da coisa em si mesma. [...] Segundo, algo é naturalmente adaptado

14 ST I-II q. 95 a. $4 c$.

15 ST I-II q. 95 a. 4 ad 1. 
a outrem, não segundo a razão absoluta da coisa em si, mas tendo em conta as suas consequências: por exemplo, a propriedade privada. Com efeito, a considerar tal campo de maneira absoluta, nada tem que o faça pertencer a um indivíduo mais do que a outro. Porém, considerado sob o ângulo da oportunidade de cultivá-lo ou de seu uso pacífico, tem certa conveniência que seja de um e não de outro, como o Filósofo o põe em evidência. Ora, apreender as coisas de maneira absoluta não convém apenas ao homem, mas também aos animais. Eis por quê, o direito chamado natural, no primeiro sentido, nos é comum, a nós e aos animais. 'Do direito natural assim entendido, afasta-se o direito das gentes', no dizer do Jurisconsulto, 'pois, aquele é comum a todos os animais, este, porém, somente aos homens entre si. Ora, considerar alguma coisa, confrontando-a com suas consequências, é próprio da razão. Portanto, isso é natural ao homem, segundo a razão natural, que dita esse proceder. ${ }^{16}$

O intuito desse último trecho é distinguir o direito das gentes do natural. Causa estranheza, então, que aquele seja apresentado como um ramo do ius naturale. Com efeito, o parágrafo começa definindo o ius gentium como um dos modos de apreensão daquilo que é adequado por natureza. Parece consistir em um subtipo do que é justo por exigência natural. Logo adiante, porém, no mesmo trecho, a consideração racional das consequências de condutas e instituições aparece como a marca distintiva do direito dos povos. O autor opera uma distinção dentro daquilo que é igual por natureza. Segundo Tomás, essa igualdade pode derivar da simples consideração da coisa, o que constituiria uma exigência do direito natural; ou do exame conjunto do objeto e das consequências às quais a relação pode levar. Esse último modo de apreender a igualdade seria típico do direito das gentes. Ora, considerar as coisas em relação com suas consequências é específico do ser humano (exclui os demais animais), pois se trata de um procedimento racional.

Mas lembre-se que também a consideração da coisa em sentido absoluto somente pode ser empreendida, no sentido estrito da expressão, pelo ser dotado de razão. Os animais não "consideram" propriamente as coisas, pois não conseguem nomeá-las, apreender sua essência nem abstrair de sua aparência ${ }^{17}$. Logo, o que distingue os dois direitos (natural e das gentes) não é a capacidade dos irracionais em compreender um deles, e sim o fato de que o direito natural existe independentemente da

16 ST II-II q. 57 a. 3.

17 Sobre o modo de conhecimento dos animais irracionais, cf. ST I-II q. 6 a. 2 c. vontade e até mesmo da consciência dos partícipes em uma relação envolvendo coisas. Isso pode ser comparado, embora impropriamente (Santiago Ramírez fala em uma analogia imperfeita ${ }^{18}$ ), com a adequação entre algum bicho e certa coisa, como seu alimento específico. Da mesma forma que entre o animal e sua presa há uma adequação que independe de suas vontades e nem foi estabelecida por ambos, assim, também, nas relações humanas, há algumas igualdades implícitas. Ora, a relação entre predador e presa somente pode ser dita "direito" caso se entenda este termo apenas como uma proporção entre um sujeito e um objeto. Nesse sentido, o animal menor está "ajustado" ao carnívoro para servir-lhe de alimento, e a planta está "ajustada" ao herbívoro na mesma proporção. É neste sentido que qualquer animal pode "considerar a coisa em absoluto", pois sabe, instintivamente, aquilo que lhe convém e aquilo que lhe é nocivo. Falando em sentido estrito, porém, um irracional encontra-se fora de todo o direito, tanto natural como das gentes, pois não possui capacidade para exigir nada, muito menos para atribuir a outro o que lhe é devido justamente. Não é, pois, a suposta participação dos animais brutos no direito natural o que o distingue do ius gentium. Tomás realiza tal comparação apenas para ilustrar a falta de necessidade do consentimento humano para a formação do direito natural. Bem como em deferência aos juristas romanos, seus referenciais intelectuais nas discussões sobre justiça e direito.

Há, então, duas maneiras de buscar o justo nas coisas: a primeira é a observação simples descrita no parágrafo anterior. A segunda é a do ius gentium: As regras de direito das gentes precisarão contar com a anuência de muitos indivíduos (ou povos), pois a avaliação das consequências das relações pode levar a muitas conclusões diferentes, e será necessário escolher. Aproxima-se, assim, o direito das gentes do consenso humano. Já o direito natural se desenvolve em outro sentido: é o resultado de um exame simples das coisas que estão na relação, sem entrar no mérito da possível conveniência da solução.

Portanto, no Tratado da Justiça, o direito das gentes parece ser natural a princípio, porém, ao cabo possui mais afinidade com o direito positivo ${ }^{19}$.

18 RAMÍREZ, Santiago Maria. El derecho de gentes o natural en Santo Tomás de Aquino (1225-1274). Editado por Carlos Rubén Terceiro-Muiños. San Luis: Universidad Católica de Cuyo, 2007, pag. 18.

19 Interpretando a passagem do Tratado da Justiça que se discute 
Essa interpretação dos artigos acima expostos não é incontroversa ${ }^{20}$ : a maior parte das opiniões sobre esses trechos se limitam a descrever as primeiras tendências de cada passagem, chegando, assim, a resultados diametralmente opostos ao que se defendeu. Para o organizador da parte geral do Tratado da Lei na edição espanhola da Suma Teológica feita pela Biblioteca de Autores Cristianos, por exemplo, o ius gentium ali seria positivo. No Tratado da Justiça, o Aquinate teria optado por classificá-lo juntamente ao natural ${ }^{21}$. Também Peter Haggenmacher qualifica o direito das gentes tomista como uno em aparência, mas essencialmente equívoco e resultado de uma tentativa do autor da Suma de conciliar posições radicalmente contrárias, apresentando-o como um conjunto de leis positivas no Tratado da Lei, e como associado ao justo natural no Tratado da Justiça ${ }^{22}$. Santiago Ramírez ${ }^{23}$ e Luiz Henrique de Azevedo ${ }^{24}$ interpretam ambas as passagens como aproximando o direito das gentes do natural, sendo aquele formado pelas conclusões imediatas que se poderiam extrair dos princípios gerais da lei natural ${ }^{25}$. Paulo Emílio de Macedo ${ }^{26}$ se aproxima dessa

aqui, Ortiz Treviño comenta que "Santo Tomás, sobre todo seguidor del estagirita [sic], no omite el carácter convencional del ius gentium, es decir, como producto de un pacto o convenio entre los hombres y es por esto que lo considera derecho positivo." ORTIZ TREVIÑO, Roberto Gerardo. La naturaleza jurídica del ius gentium de acuerdo con la doctrina de Francisco de Vitoria. Estudio breve en honor al pensamiento de Antonio Gómez Robledo. In: Anuario Mexicano de Historia del Derecho, vol. XVII, pag. 39.

20 No sentido aqui defendido, embora de modo sintético, cf. CHROUST, Anton-Hermann. The 'Ius Gentium' in the Philosophy of Law of St. Thomas Aquinas. In: Notre Dame Law Review, vol. 17, n. 1 (1941), pag. 26.

21 OSUNA FERNÁNDEZ-LARGO, Antonio. Comentário à I-II q. 95 a. 4. In: AQUINO, Santo Tomás de. Suma de Teología, tomo II, $2^{\mathrm{a}}$ ed. Madri: Biblioteca de Autores Cristianos, 1989, pag. 744.

22 HAGGENMACHER, Peter. Grotius et la doctrine de la guerre juste. 1983. Tese (Doutorado) - Institut Universitaire de Hautes Études Internationales, Genebra, pag. 330.

23 RAMÍREZ, Santiago Maria. El derecho de gentes o natural en Santo Tomás de Aquino (1225-1274). Editado por Carlos Rubén Terceiro-Muiños. San Luis: Universidad Católica de Cuyo, 2007.

24 AZEVEDO, Luiz Henrique Cascelli de. Ius Gentium em Francisco de Vitoria: a fundamentação dos Direitos Humanos e do Direito Internacional na tradição tomista. Porto Alegre: Sergio Antonio Fabris, 2008, pag. 114 et seq.

25 Vale mencionar a interpretação de Francisco Castilla Urbano, que expõe a distinção entre direito natural e ius gentium da q. 57 a. 1 como revelando a proximidade entre ambos. Assim, Tomás estaria "reconhecendo-o [o direito das gentes] também como um direito que difere do natural somente em relação as [sic] suas consequências, absolutas em um e adaptadas à razão humana no outro." CASTILLA URBANO, Francisco. Francisco de Vitoria. In: DAL RI JR., Arno; VELOSO, Paulo Potiara de Alcântara; LIMA, Lucas Carlos (orgs.). A Formação da Ciência do Direito Internacional. Ijuí: Ed. Unijuí, 2014, pag. 134.

26 MACEDO, Paulo Emílio Vauthier Borges de. Uma com- interpretação, acrescentando que o ius gentium tomista abrangeria as conclusões extraídas da lei natural como consequência de situações criadas por condutas humanas. Já Michel Villey não vê oposição entre os dois trechos, que para ele exprimem um ius gentium que reflete o direito natural nos casos concretos (mas não a lei natural $)^{27}$.

Comparados entre si, os dois parágrafos do Aquinate parecem contradizer-se, tanto no que aparentam quanto no que realmente exprimem. Para colmar a dissonância, tome-se um trecho do Comentário à Ética a Nicômaco, em que o mestre de Roccasecca adota uma perspectiva ligeiramente distinta do direito das gentes:

Aristóteles considera o justo natural como o
regramento para o qual se inclina a natureza humana,
no entanto, percebemos que há no homem duas
espécies de naturezas: Uma é a natureza animal, isto
é, a que o homem compartilha com os animais. A
outra lhe é própria, não a compartilhando com os
outros seres inferiores, isto é, a natureza do 'homem
enquanto homem', gestada pela racionalidade e
concretizada na capacidade de discernir o torpe do
honesto. Os juristas, porém, dizem somente que
o justo é natural quando em conformidade com
a inclinação da natureza comum ao homem e aos
outros animais, tal qual a união entre o marido e a
esposa, a educação dos filhos e outras atividades das
relações familiares. Mas bem diferente é o Direito
que segue a inclinação própria da natureza humana
- a natureza racional. Os juristas a chamam de
direito das gentes, pelo fato de que todos os povos
a utilizam. Segundo os juristas, é regra do Direito
das Gentes as propostas de que os pactos devem
ser cumpridos, e de que as legações são imunes
e protegidas, mesmo entre inimigos. Ambas as
espécies de Justiças são compreendidas pelo justo
natural como foi, neste ponto da Ética, apresentado
pelo Filósofo.

Aqui, o direito das gentes é o direito próprio das inclinações específicas da natureza humana. Em oposição ao direito natural, o qual — segundo os "juristas" - aplicar-se-ia ao homem e aos animais nos aspectos acima transcritos. É notável, nessa passagem, o rol de exemplos que o Aquinate toma dos comentadores do direito romano. $\mathrm{O}$ direito das gentes adquire um con-

paração entre os conceitos de Jus Gentium em Francisco Suárez e Hugo Grócio. 2007. Tese (Doutorado em direito) - Universidade do Estado do Rio de Janeiro, Rio de Janeiro, 2007, pags. 46-52.

27 VILLEY, Michel. Considérations intempestives sur le droit des gens. In: Archives de philosophie du droit, v. 32: le droit international (1987).

28 AQUINO, Santo Tomás de. Da Justiça. (Título original: "Sententia libri Ethicorum, Liber 5".) Tradução de Tiago Tondinelli. Campinas: Vide Editorial, 2012, Lição XII. 
torno internacionalista, enquanto, nos trechos da Suma comentados, as ilustrações do ius gentium eram de outra índole - justiça na compra e venda e conveniência da propriedade privada.

A multiplicidade de significados possíveis que se viu nesse apartado será reduzida a partir das próximas seções. Iniciar-se-á pela análise contextual das passagens discordantes da Suma Teológica.

\section{O IUS GeNTIUM NO CONTEXTO dA SUMA TEOLÓGICA}

Da apresentação dos trechos relevantes do Aquinate, algumas indagações se fazem presentes: em suma, o que é o ius gentium para Santo Tomás de Aquino? Insere-se no direito natural ou no positivo? Como conciliar os trechos díspares da Suma que o abordam? É indicado seguir a mesma ordem que o Doutor Angélico. Iniciar-se-á, pois, pela análise do Tratado da Lei.

\subsection{O Tratado da Lei}

Ao estudar a lei humana enquanto um dos princípios extrínsecos que movem a ação dos homens, o artigo $4^{\circ}$ da questão 95 pergunta se ela pode ser dividida de acordo com a tradicional definição que Isidoro de Sevilha, autor das Etimologias, dava do ius, decompondo-o em lei natural, direito das gentes e direito civil ${ }^{29}$. Vale notar que o termo "lei humana" aqui não se deve entender em contraste com a lei natural, mas com a lei divina, pois esta é a primeira divisão que Isidoro faz ${ }^{30}$. A primeira objeção levantada por Tomás à utilidade das Etimologias refere-se ao fato de que Isidoro mencionou o direito das gentes na rubrica relativa ao direito humano, quando na realidade deveria pertencer ao direito natural.

A melhor resposta seria notar que a lei natural, que o bispo sevilhano não diferencia do direito natural, também se inclui no direito humano, dado que a outra alternativa seria o direito divino. Com efeito, Isidoro entende

29 HAGGENMACHER, Peter. Grotius et la doctrine de la guerre juste. 1983. Tese (Doutorado) - Institut Universitaire de Hautes Études Internationales, Genebra, pags. 320-321.

30 ISIDORO DE SEVILLA. Etimologías. Edición bilingüe. Versão ao espanhol de José Oroz Reta e Manuel-A. Marcos Casquero. Madri: Biblioteca de Autores Cristianos, 2004, pag. 501. Disponível em: < http://www.larramendi.es/i18n/consulta/registro. cmd?id=5374 >. Acesso em: 01.09.2018. direito humano como simplesmente "ius", ao contrário do divino, que seria o "fas" das permissões de Deus. Desde o advento de Roma, ius e fas eram considerados lado a lado como os aspectos respectivamente profano e sagrado, ou justo (segundo o direito) e lícito (por permissão dos deuses) ${ }^{31}$. Essa distinção ainda encontra eco em Tomás de Aquino: ao conceituar o direito, ocupa-se em separá-lo do $f a s^{32}$. Poder-se-ia criticar a colocação lado a lado de três espécies (direitos natural, das gentes e civil) pertencentes a dois níveis de classificação distintos: o direito das gentes estaria em um segundo ní$v^{3}{ }^{33}$. Porém, a mera presença do ius gentium na categoria "direito humano" não é uma impropriedade, segundo o sentido que as Etimologias dão aos termos.

Contudo, o Aquinate responde de modo diverso e mais complexo, aproveitando a questão para especificar a relação entre a lei humana e a natural. O desenvolvimento do corpus do artigo mostra que Santo Isidoro foi citado em virtude da descrição dos vários tipos de leis que empreende. Ele se aprofunda nas diversas categorias do ius civile, o que dá ao Doutor Angélico oportunidade para abordar diversos aspectos do modo em que as normas jurídicas realizam e complementam a tarefa da lei natural.

A resposta começa estabelecendo um princípio metodológico: para saber se a divisão proposta por Isidoro de Sevilha é "aceitável”, o critério utilizado será verificar se a mesma parte de algum elemento essencial da lei. A boa divisão será aquela que classifica as espécies de um gênero de acordo com os distintos modos em que a pertença ao gênero se manifestar. No caso da lei, o autor das Etimologias elegeu, segundo Santo Tomás, a derivação de toda lei da lei natural como aspecto comum, operando a divisão de acordo com o modo como esta derivação ocorre ${ }^{34}$. Daí a apresentação dos três tipos de

31 URDÁNOZ, Teofilo. Introducción a la cuestión 57. In: AQUINO, Santo Tomás de. Suma Teológica, t. VIII. Madrid: Biblioteca de Autores Cristianos, 1956, pag. 181

32 "Non dicitur proprie ius lex divina, sed fas..." ST II-II q. 57 a. 1 ad 3. A palavra grifada encontra-se em itálico no original. Em tradução livre: "A lei divina não se chama propriamente direito, e $\operatorname{sim} f a s$ ".

33 AZEVEDO, Luiz Henrique Cascelli de. Ius Gentium em Francisco de Vitoria: a fundamentação dos Direitos Humanos e do Direito Internacional na tradição tomista. Porto Alegre: Sergio Antonio Fabris, 2008, pag. 84.

34 "Cada coisa pode [...] dividir-se segundo aquilo que se contém em sua razão. [...] Há muitas coisas da razão da lei humana, segundo as quais qualquer lei humana pode dividir-se propriamente [...] Primeiramente, é da razão da lei humana que seja derivada da lei da natureza..." ST I-II q. 95 a. 4 c. 
direito: natural, civil e das gentes.

Em relação à objeção que considerava o direito das gentes como parte do direito natural, deve ser observado que o Aquinate a aceita em grande parte ${ }^{35}$. Pois diz que pertencem ao direito dos povos aquelas conclusões derivadas da lei natural que a tomam por princípio. $\mathrm{O}$ exemplo é o da justiça nas relações de compra e venda. Aduz que são conclusões próximas dos postulados da lei natural. Por um lado, tão próximas que a tendência é que todos concordem sem muito esforço sobre seu teor. Mas há uma separação: o direito das gentes não se identifica com a parte da lei natural que é comum aos animais. Contudo, nessa última sentença, Tomás de Aquino excedeu a classificação de Isidoro: recorde-se que o prelado ibérico operava dentro de uma primeira e magna divisão, entre direito humano e divino. Seu direito das gentes é humano, mas também seu direito natural. Não existe a categoria "direito animalesco" nas Etimologias. Caso se interprete este artigo da Suma como uma explicação do texto de Santo Isidoro, a conclusão será que, para o Aquinate, a lei natural e o direito das gentes seriam a mesma coisa. Somando-se o contorno "direito humano" de Isidoro ao critério de distinção de Tomás entre ius gentium e ius naturale, não é mais possível separá-los.

Ora, o intuito da Suma, como dito acima, não era comentar as Etimologias. A referência a essa última obra deve ser interpretada restritivamente, não se devendo assumir que o Aquinate concordava com tudo o que ali estava. A conclusão deve ser então matizada: no Tratado da Lei, o direito das gentes está mais próximo ao direito natural. Embora não se identifique com este: é uma derivação da lei natural. Derivação realizada a modo de dedução $0^{36}$.

Assim, os trechos desse Tratado, em que se afirma que o ius gentium é de direito natural, devem ser compreendidos como uma qualificação: se enfatiza sua maior proximidade com o direito natural do que com o

35 BARRETTO, Rafael Zelesco. O caso hipotético da morte do embaixador francês na Espanha: duas espécies de ius gentium em Francisco de Vitoria. Revista de Direito Internacional, Brasília, v. 14, n. 2, 2017, pag. 539.

36 Respondendo à questão "Toda lei posta pelo homem deriva da lei natural?", Tomás enfrenta a objeção segundo a qual "Aquelas coisas que derivam dos princípios comuns da lei da natureza, como conclusões, pertencem à lei da natureza...”, que ele não rejeita, apenas modula para "aquela razão procede [apenas] a respeito daquelas coisas que derivam da lei da natureza como conclusões" ST I-II q. 95 a. 2 obj. 2 e ad 2. direito positivo. Esse último também deriva da lei natural, porém, de outra maneira, isto é, por determinação. Aqui as comunidades humanas (civitas) escolhem, livremente, o que mais lhes convém, dentro do espaço deixado pela lei natural — que é expressivo, como já visto.

Consequentemente, a divisão isidoriana tripartite está correta caso seja considerada quanto à relação entre lei humana e lei natural. Assim, ter-se-á, primeiramente, a lei natural, a qual informa tanto o direito das gentes, por via de conclusão, quanto a lei civil, por determinação. O direito das gentes é um componente necessário desta divisão, pois a lei humana origina-se da lei natural por dois modos distintos. Faz parte da lei humana, mas se situa mais próximo à lex naturalis do que os diversos ordenamentos das repúblicas. O exemplo mencionado por Tomás de Aquino nesse passo - justiça nas transações de compra e venda - se encontra extremamente próximo do que pode ser naturalmente compreendido com aplicação da razão humana às coisas. No Tratado da Lei, então, o direito das gentes situa-se na vizinhança imediata do ius naturale. Resta ver se tal ordenação se mantém quando o Doutor Angélico se volta especificamente ao direito e à justiça.

\subsection{O Tratado da Justiça}

No Tratado da Justiça, estudam-se os atos humanos, especificamente aqueles que tendem à virtude da justiça, ou a seu contrário, a injustiça. O ius gentium aqui é agraciado com um artigo inteiro: "o direito das gentes é o mesmo que o direito natural?" ${ }^{37}$ Embora pareça ser o protagonista, o direito das gentes, mais uma vez, foi citado, apenas, a título de pretexto: Michel Villey nota que o propósito do artigo é apresentar as formas pelas quais se pode conhecer o direito natural ${ }^{38}$. Se algo for tido universalmente por correto, será devido por uma exigência da natureza?

Já se viu que o Aquinate fornece um caminho dúplice para chegar ao justo natural. Uma via consiste na observação dos bens na relação e da igualdade que já existe entre os partícipes da mesma. Outra observa as possíveis consequências das relações envolvendo coisas; trata-se de um juízo mais afim à utilidade e conveniência. $\mathrm{O}$ exemplo desse segundo modo de proceder

\section{$37 \quad$ ST II-II q. 57 a. 3.}

38 VILLEY, Michel. Questões de Tomás de Aquino sobre direito e política. São Paulo: Martins Fontes, 2014, pags. 131-152. 
refere-se à propriedade, mais especificamente à propriedade privada dos terrenos. Por sua própria natureza, a terra não manifesta nenhuma exigência de que seja dividida. Contudo, observando certo pedaço de terra com alguma intenção específica - Tomás menciona duas: o melhor proveito do campo e a manutenção da paz - é possível concluir que ele corresponderá melhor ao bem de certa sociedade caso seja dividido entre as pessoas: "tem certa conveniência que seja de um e não de outro" 39 . Ora, o que aproveita à comunidade pode ser objeto de divergências, e dependerá em parte das condições físicas de cada sociedade. Será necessário proceder a uma escolha entre as várias opções possíveis — em relação ao exemplo do campo, muitos povos adotaram o nomadismo, outros a propriedade comunal. Note-se a respeito que o exemplo dado refere-se a um campo (não "aos campos") e a uma pessoa determinada (o campo será de "um" e não de "outro") ${ }^{40}$. Isto é, trata-se de relações jurídicas singulares, não do estabelecimento de regras gerais. $\mathrm{O}$ direito das gentes é um direito, não uma lei - e para Tomás, como se recorda, são dois termos distintos. Portanto, este ius buscará a parte devida a cada um a partir de considerações gerais sobre as coisas - embora mais específicas que o raciocínio do direito natural. O diferencial é que o ius gentium provém de um raciocínio deliberativo, pelo qual se preveem os possíveis resultados das decisões no seio de uma sociedade específica. Retornando ao exemplo do Aquinate, a "este campo" pode convir uma divisão, a outro não.

Vale a pena acompanhar o retorno da discussão tomista sobre a propriedade privada no estudo sobre o furto. Ao analisar esse vício contrário à virtude da justiça, o teólogo medieval se ocupa, preliminarmente, em estabelecer a legitimidade da propriedade em si. Nesta Quaestio 66 da Secunda Secundae, é interessante notar que a justificação da apropriação privada é feita em dois artigos distintos. O primeiro indaga se a posse de bens exteriores é natural ao homem ${ }^{41}$. Após a resposta afirmativa, o artigo seguinte questiona o caráter privado da propriedade ${ }^{42}$. A segmentação da discussão deve-se ao fato de que as bases de justificação diferem: Tomás não encontra dificuldades para afirmar que todo homem possui um domínio natural sobre o restante da Cria-

39 ST II-II q. 57 a. 3.

40 VILLEY, Michel. Considérations intempestives sur le droit des gens. In: Archives de philosophie du droit, v. 32: le droit international (1987), pag. 19.

41 ST II-II q. 66 a. 1.

42 ST II-II q. 66 a. 2. ção, pois os seres mais imperfeitos existem para os mais perfeitos. O problema surge no ponto seguinte: a apropriação de um bem com exclusividade não seria manifestação de um egoísmo antissocial e anticristão ${ }^{43}$ ? Pior ainda, não se estaria fraudando o direito natural, que se abstém de atribuir os bens a indivíduos singulares ${ }^{44}$ ? Em resposta, sugerem-se três argumentos bastante realistas: os homens tendem a cuidar menos das coisas que possuem em comum, fiando-se no esforço dos outros; a administração das propriedades comuns é confusa; e as posses indivisas são mais aptas a suscitar contendas entre seus donos ${ }^{45}$.

Resta combater a objeção que apontava a inaturalidade da propriedade privada. E a Suma apela ao ius gentium, embora sem nomeá-lo: quando se diz que a comunidade dos bens é de direito natural, isto não constitui uma proibição intransponível (como seria o caso diante da lei natural), mas uma constatação de que a natureza das coisas não dividiu nada entre ninguém. Não é necessário que as sociedades se imobilizem perante esse fato; a convenção humana pode proceder às repartições caso isto seja considerado conveniente - e Tomás argumenta, como se viu, pelas vantagens da privatização das propriedades, com base no que via em seu mundo. "A divisão das posses não vem do direito natural, porém de convenção humana, dependendo, portanto, do direito positivo" "46. Essa sentença é reveladora: cada república divide os bens que há nela como reputar mais adequado: âmbito do direito positivo.

Mas a divisão das propriedades não havia sido exatamente o exemplo escolhido pelo Aquinate para ilustrar um dos modos de encontrar o direito natural? Como se viu há poucos parágrafos, o estabelecimento do ius naturale através da consideração das consequências das coisas foi demonstrado com base no caso da repartição dos bens. Se, então, se falava sobre direito natural, como, agora, na questão sobre o furto, o dominicano afirma que a distinção das posses se deu por direito positivo? Nota-se ainda que este último trecho faz uma remissão ao primeiro. Isto é, não se trata de um lapso do Doutor Angélico - que seria inverossímil dada a proximidade entre ambas as passagens.

A aparente contradição deve, então, ser entendida

\footnotetext{
43 ST II-II q. 66 a. 2 obj. 2.

44 ST II-II q. 66 a. 2 obj. 1.

45 ST II-II q. 66 a. 2 c.

46 ST II-II q. 66 a. 2 ad 1.
} 
no sentido de que é a razão humana a responsável pela divisão das coisas. Com efeito, o segundo modo de encontrar o direito natural, observando as hipotéticas consequências que podem advir das diversas condutas possíveis, somente pode ser empreendido com o auxílio decisivo da razão humana. Não se trata de uma operação silogística, na qual a lei natural assuma a premissa maior, a "consideração das consequências" integre a menor, e a solução de direito natural surja como conclusão irrefutável. $\mathrm{Na}$ verdade, o direito natural aqui dependerá do esforço propositivo da razão humana — um esforço deliberativo, como deixa claro o Aquinate ao falar em "convenção" - de alcançar uma solução justa considerando certas circunstâncias específicas. E deve ser dito que essa deliberação racional não busca uma correção absoluta, universalizável. São levadas em conta as características próprias sob as quais os habitantes daquela república vivem, e esta é a tarefa do ius gentium.

É o que se depreende de um último retorno às razões oferecidas pelo Doutor Angélico em prol da propriedade privada. Note-se que Seus argumentos aí não exibem pretensão de generalização universal. Os três são graduais, indicando que as consequências sociais são melhores quando cada um possuir seus bens - mas não se condena o estado contrário. E o raciocínio se baseia na experiência e no senso comum: a propriedade coletiva é menos cuidada "como acontece quando há uma [grande] quantidade de criados na casa" $"$, ter um bem como próprio contribui para a paz social, pois se vê "surgirem frequentes litígios entre os que têm posses comuns e indivisas" ${ }^{\text {" }}$. Em outras circunstâncias, sob outro regime econômico ou condições demográficas diferentes, ou ainda em uma cultura que enxergasse os bens de forma distinta, a solução, talvez, fosse outra. Nas condições em que vivia Tomás de Aquino, a propriedade privada parecia o sistema mais adequado ao menos até prova em contrário. O exemplo da legitimação da propriedade privada é claro: esse segundo direito natural, encontrado com base na consideração das consequências e que é apelidado de ius gentium no artigo, possui algo de direito positivo.

Essas considerações se encontram, na verdade, muito próximas das especificações da lei natural encontradas a modo de determinação, que haviam sido mencionadas no Tratado da Lei. Mas há um problema: ali, o ius

47 A tradução consultada omitiu o termo "grande". Conferir o original: "sicut accidit in multitudine ministrorum" (grifo acrescentado). 48 ST II-II q. 66 a. $2 c$. gentium era descrito como oriundo de um processo de mera conclusão a partir de princípios. Aqui, na questão sobre o furto, ele necessita de uma operação de deliberação. Aparentemente, Tomás de Aquino se contradiz em relação à forma de encontrar o direito das gentes.

A dúvida se desfaz quando se atenta para a pergunta que está sendo respondida em cada seção: no estudo sobre a lei, se deseja saber como se derivavam outras leis da lei natural. Ao tratar da justiça, investiga-se como se pode conhecer o direito natural. No primeiro caso, emprega-se o modo dedutivo, partindo da generalidade da lei natural para chegar às particularidades da vida dos homens através de outras leis, formas de concretização da lei natural. No segundo, pratica-se o modo indutivo, que conduz da coisa justa singular ao método genérico que se empregará para conhecê-la: a partir do justo por exigência natural, intenta-se alcançar algum princípio que indique no que consiste exatamente o direito natural. No Tratado da Lei, o direito positivo é o objeto da pergunta; no Tratado da Justiça, busca-se o direito natural. Essa diferença de enfoque faz com que o ius gentium, embora seja um instituto único para Tomás, tenha, em cada Tratado, realçada sua proximidade, respectivamente, com o direito natural e com o positivo. A diferença é mais de ênfase que de substância.

Para compreender bem o tema, é mister lembrar que as palavras "direito" e "lei" revestem, para Tomás, significados expressivamente distintos. Em síntese, a lei indica, no plano abstrato e genérico, a medida da coisa justa a ser depois definida em cada caso concreto, no que consistirá o direito. Logo, as formulações acerca do direito das gentes nos dois trechos da Suma que se contrastam aqui não possuem exatamente o mesmo sentido. Isto porque o que se convencionou chamar de teoria jurídica de Santo Tomás é composta de duas partes: uma reflexão sobre a ordenação das coisas, desde o cosmos até as relações particulares, que se realiza através da lei. E um estudo sobre a arte e o modo de dar a cada um o que lhe cabe, exercendo a virtude da justiça em prol do direito. As duas partes comportam, cada, um plano natural e um humano. Assim, ao tratar da promoção da ordem na sociedade, menciona-se a lei natural e a lei positiva. Versando sobre o suum cuique, tem-se o direito natural e o positivo. Todos esses termos possuem significados específicos e respondem a um problema diferente, não podendo ser reduzidos a sinônimos: lei natural e direito natural não se identificam; o direito positivo utiliza, mas não se reduz, à lei positiva. 
No que tange ao ius gentium, nota-se que ele se encontra no âmbito do justo, ao lado do direito natural e do positivo. Contrariamente a estes, porém, não exibe um correspondente relacionado com a lei: a questão relativa a ele no Tratado da Lei continua a referir-se ao ius gentium $^{49}$. Não se vê uma lex gentium ${ }^{50}$, o que faz todo sentido quando se recorda que a lei é uma ordenação da razão promulgada com vistas ao bem comum. No mundo de Tomás (como de resto no atual), não havia sentido em imaginar a figura de um legislador universal. Ainda que o Papa e o Imperador do Sacro Império Romano Germânico eventualmente se arrogassem tais títulos, eles jamais detiveram poder para legislar, efetivamente, sobre as gentes da Europa. Suas pretensões universalistas baseavam-se mais na faculdade de influenciar outros governantes ou de vetar políticas específicas que os prejudicassem. Seja como for, é um fato que a obra política do teólogo de Roccasecca ignora a existência de um autor universal para a lex gentium. A natureza também não assume esse papel, como fica claro do exame do Tratado da Lei, em que a lex naturalis é minuciosamente discutida, sem que a extensão de suas conclusões ao modo de vida dos diversos povos seja mencionada como efeito.

Provavelmente, essa ausência da lex gentium foi causada também pelo respeito do Aquinate à linguagem de seus mestres na arte do direito, os velhos jurisconsultos latinos. Ela é útil não apenas para captar o caráter intermediário do direito dos povos, mas para reforçar a relação entre lei e direito: a primeira é logicamente anterior ao segundo, pois determina o que é de cada um em geral, ao que o direito segue com a tarefa de particularizar a diretriz legal levando em conta a proporção que emana do caso concreto. Assim, o direito das gentes possui

49 Dessa dissonância vocabular poder-se-ia inferir que, no tema do direito das gentes, o estudo do direito, feito no Tratado da Justica e onde o ius gentium se aproxima mais do direito positivo, possui prioridade sobre o estudo da lei efetuado no Tratado da Lei e no qual se enfatiza a proximidade do ius gentium com a lei natural. Como o autor mantém o termo "ius" no Tratado da Lei, seria defensável afirmar que, para ele, se tratava de um ramo do direito e não da lei, e que o Tratado da Justiça representaria o núcleo do exame tomista do direito dos povos. Contudo, esse argumento possui força apenas relativa e probabilística.

50 Daniel Herrera entende que, no Tratado da Lei, o ius gentium é considerado em uma perspectiva de lex gentium, a qual comporia a razão do direito das gentes do Tratado da Justiça. Cf. HERRERA, Daniel Alejandro. Ius gentium: ¿derecho natural o positivo? In: ZORROZA, Maria Idoya (org.). Proyecciones sistemáticas e históricas de la teoría suareciana de la ley: Jornadas de Iustitia et Iure en el Siglo de Oro. Buenos Aires, 2008, pag. 48. uma dimensão legal, que está próxima da lex naturalis tal qual as primeiras conclusões que se derivam de princípios; e uma dimensão propriamente jurídica, mais afim ao direito emanado da vontade humana, como um primeiro raciocínio superficial sobre a adequação de uma divisão a certa sociedade.

A diferença de tratamento do ius gentium faz sentido, então, quando se observa que se trata de um meio termo entre os direitos natural e positivo ${ }^{51}$. É um princípio recorrente no raciocínio tomista o de que o meio entre dois termos parece igualar-se a cada um dos extremos, caso comparado com o outro. "O que está no meio, se comparado a um dos extremos, parece com o outro, pois participa da natureza de ambos. Como exemplo, o morno é frio em relação ao quente, e é quente em relação ao frio." ${ }^{52}$ Sendo assim, a alternância entre direito natural e positivo representa uma forma de Tomás expressar a situação do direito das gentes, notando-se, também, a relativa falta de interesse pessoal dele no tópico — não é um jurista ${ }^{53}$. Portanto, no Tratado da Lei, quando inquiria sobre o direito positivo, o direito das gentes foi apresentado como lei natural. Exatamente o oposto se deu no Tratado da Justiça.

Esclarecidos esses pontos, pode-se intentar definir o direito das gentes para Tomás de Aquino. Combinando-se os dois momentos em que a Suma o menciona expressamente, tem-se que é uma conclusão próxima da lei natural, cuja aplicação se faz por determinação. Compõe-se de princípios dedutíveis com facilidade das regularidades da lei natural, mas neles já intervém a vontade humana, na forma de uma escolha, como o exemplo da conveniência de dividir ou não um campo deixa patente. Esse influxo do querer humano se faz de modo ainda embrionário e pouco consciente, diferentemente da instituição solene das leis positivas.

Essa interpretação parece a única que dá pleno sentido a todas as citações do Aquinate feitas nesse tópico. Fica evidente que o direito das gentes era, para ele,

51 AZEVEDO, Luiz Henrique Cascelli de. Ius Gentium em Francisco de Vitoria: a fundamentação dos Direitos Humanos e do Direito Internacional na tradição tomista. Porto Alegre: Sergio Antonio Fabris, 2008, pag. 111.

52 ST I q. 108 a. 4 ad 5.

53 "Contudo, são Tomás [sic] só falava do jus gentium por uma preocupação concordista e para dar conta dos textos de Gaio e de Ulpiano; embora se costume ensinar o contrário, não considero essa noção essencial ao seu sistema das fontes do direito." VILLEY, Michel. A formação do pensamento jurídico moderno. São Paulo: Martins Fontes, 2005, pag. 387. Grifos mantidos. 
uma espécie de meio termo entre o natural e o positivo, que não se identificava plenamente com nenhum dos dois. Logicamente, deve haver, então, um elemento que o diferencie de ambos os extremos. Em relação ao direito natural, tal separação somente pode ocorrer pela intervenção da vontade humana. E, a respeito do direito positivo, a diferença está em que tal vontade se manifesta de modo inconsciente, abrangendo várias repúblicas - daí o nome "direito dos povos". Esse direito das gentes não pode ser confundido com o costume vigente nas várias cidades, que também integra o direito civil local. Então, o ius gentium compreenderá as práticas repetidas em diversas repúblicas, que refletem, de modo mais imediato, a lei natural. É a primeira concretização do direito natural em seu percurso rumo à resposta correta para um determinado caso. Se o direito, em Santo Tomás, designa a parte que deve ser entregue ao outro em uma relação envolvendo bens, o direito das gentes é o primeiro contorno dessa parte justa. Insuficiente para resolver um litígio, porém já excluindo as soluções que, claramente, não são adequadas.

O que Tomás não diz é como exatamente encontrar esse direito das gentes. $\mathrm{Na}$ falta de indicação direta, é possível recorrer às fontes por ele citadas. A próxima seção, então, estudará a descrição romana do ius gentium, muito voltada à prática e com um sabor cosmopolita que deveria soar exótico e atraente aos olhos de um estudioso medieval.

\section{O IUS GENTIUM NAS FONTES ROMANAS DE Tomás de Aquino}

Uma das primeiras autoridades invocadas pelo Aquinate é o bispo Isidoro de Sevilha, que, de certa forma, pelo momento em que viveu, constituiu um receptáculo da cultura romana legada à Idade Média. Isidoro de Sevilha descreve o ius gentium em um parágrafo:

\footnotetext{
El derecho de gentes se manifiesta en la ocupación de terras, construcciones de edifícios, fortificaciones, guerras, prisioneros, servidumbres, restituciones, tratados de par, armisticios; comprende también la inviolabilidad de los embajadores o la probibición de contraer matrimonio con personas extranjeras. $Y$ se llama derecho de gentes porque tiene vigencia en casi todos los pueblos. ${ }^{54}$
}

54 ISIDORO DE SEVILLA. Etimologías. Edición bilingüe. Versão ao espanhol de José Oroz Reta e Manuel-A. Marcos Casquero. Madri: Biblioteca de Autores Cristianos, 2004, pag. 503.
Como se vê, o bispo do século VI tinha claro que o direito das gentes abarcava, principalmente, instituições voltadas às relações além-fronteiriças. Até mesmo seu último exemplo, que Haggenmacher nota encaixar-se com dificuldade entre os temas do atual direito internacional ${ }^{55}$, pode ser relacionado à repressão à espionagem, ao relacionamento entre clãs distintos na Europa da Alta Idade Média e à condição jurídica do estrangeiro. Por outro lado, nota-se que Isidoro não exige unanimidade no direito das gentes ${ }^{56}$, bastando-lhe que esteja em vigor para muitos povos ${ }^{57}$ (provavelmente, os mais próximos, mais conhecidos ou culturalmente mais afins).

Além do clérigo visigodo, citam-se algumas passagens do Digesto, mas apenas no Tratado da Justiça, no qual examina o direito propriamente. No Tratado da Lei, os juristas romanos não são consultados. Dentre as citações aproveitadas pelo Aquinate, destaca-se a seguinte, de autoria do jurisconsulto Ulpiano:

O direito natural é o que a natureza ensinou a todos os animais. Pois este direito não é próprio do gênero humano, mas de todos os animais que nascem na terra ou no mar, comum também das aves. Daí deriva a união do macho e da fêmea, a qual denominamos matrimônio; daí a procriação dos filhos, daí a educação. Percebemos, pois, que também os outros animais, mesmo as feras, são guiados pela experiência deste direito.

O direito das gentes é aquele do qual os povos humanos se utilizam. O que permite facilmente entender que ele se distancia do natural, porque aquele é comum a todos os animais e este é comum somente aos homens entre si. ${ }^{58} 59$

55 HAGGENMACHER, Peter. Grotius et la doctrine de la guerre juste. 1983. Tese (Doutorado) - Institut Universitaire de Hautes Études Internationales, Genebra, pag. 323.

56 O que já denota um traço de positividade nesta concepção de ius gentium. Cf. AZEVEDO, Luiz Henrique Cascelli de. Ius Gentium em Francisco de Vitoria: a fundamentação dos Direitos Humanos e do Direito Internacional na tradição tomista. Porto Alegre: Sergio Antonio Fabris, 2008, pag. 83.

57 TUORI, Kaius. The Reception of Ancient Legal Thought in Early Modern International Law. In: FASSBENDER, Bardo; PETERS, Anne (orgs.). The Oxford Handbook of the History of International Law. Oxford: Oxford University Press, 2012, pag. 1018.

58 JUSTINIANO I (org.). Digesto de Justiniano, livro I. Tradução de Hélcio Maciel França Madeira, $2^{a}$ ed. São Paulo: Revista dos Tribunais; Osasco: UNIFIEO, 2000, I.1.1.3-4.

59 Advirta-se que, na última frase transcrita, os termos "aquele" e "este" estão trocados na tradução. O trecho original reza: "Ius gentium est, quo gentes bumanae utentur. Quod a naturali recedere facile intellegere licet, quia illud omnibus animalibus, hoc solis hominibus inter se commune sit." (Grifos acrescentados.) A confusão estriba em referir “illud” ao "ius gentium", quando claramente se relaciona com o "(ius) naturale", 
Como lido acima, Ulpiano atribuía o ius gentium exclusivamente aos homens e o ius naturale indiferentemente a homens e animais. Frise-se que o direito romano não cingia os animais irracionais de qualquer direito, e a distinção de Ulpiano acabava por tornar-se inócua na prática ${ }^{60}$. Sua intenção talvez não fosse descrever, exatamente, o que ocorria na prática forense em Roma, e sim justificar, filosoficamente ${ }^{61}$, o conteúdo de um direito superior que limitaria a vontade dos legisladores e jurisconsultos romanos ${ }^{62}$. Para isso, chamou a atenção para institutos tão evidentes que os próprios animais os adotavam, como o casamento; e para outros menos evidentes, mas também facilmente perceptíveis, que até os atrasados bárbaros conseguiam desenvolver, como a propriedade e a escravidão, cuja outra face, a manumissão ou alforria do escravo, aparece no trecho a seguir:

Também as manumissões são do direito das gentes.
Vem, pois, a manumissão de 'demissão pela mão',
isto é, a concessão da liberdade: pois enquanto o
manumitido se liberta da potestas, o que estiver em
servidão se submete à manus e à potestas. Isto toma
origem no direito das gentes, visto que por direito
natural todos nasceriam livres e não se conheceria

dado que "ius gentium" é o sujeito da segunda frase (“Quod"), sendo pois designado pelo pronome " $h o c$ ". A tradução correta, pois, seria: "O direito das gentes é aquele do qual os povos humanos se utilizam. O que permite facilmente entender que ele se distancia do natural, porque este é comum a todos os animais e aquele é comum somente aos homens entre si." Nesse sentido, também GILISSEN, John. Introdução histórica ao direito, $3^{a}$ ed. Tradução de António Manuel Hespanha e Manuel Macaísta Malheiros. Lisboa: Calouste Gulbenkian, 2001, pag. 97; SCOTT, Samuel P. The Civil Law, vol. 2: Enactments of Justinian: Institutes, Digest (Pandects) Books I and II. Versão inglesa de Samuel P. Scott. Cincinatti: The Central Trust Company, 1932. Disponível em: < http://www.constitution. org/sps/sps02.htm > . Acesso em: 01.09.2018.

60 AZEVEDO, Luiz Henrique Cascelli de. Ius Gentium em Francisco de Vitoria: a fundamentação dos Direitos Humanos e do Direito Internacional na tradição tomista. Porto Alegre: Sergio Antonio Fabris, 2008, pags. 69-72.

61 Por isso, quanto ao ius gentium, não era importante para os romanos saber se era seguido exatamente por todos os povos; bastavalhes reconhecer a razoabilidade e simplicidade de seus preceitos para concluir que deveriam provavelmente ser replicados em toda parte. BRIERLY, J.L. The Law of Nations: an Introduction to International Law, $5^{a}$ ed. New York: New York University Press, 1955, pag. 17.

62 "Ou Ulpiano seria um mau jurista, por não descrever o jus gentium histórico com a devida acuidade, ou seria um mau filósofo, por desconhecer os fundamentos da bipartição aristotélica." MACEDO, Paulo Emílio Vauthier Borges de. Uma comparação entre os conceitos de Jus Gentium em Francisco Suárez e Hugo Grócio. 2007. Tese (Doutorado em direito) - Universidade do Estado do Rio de Janeiro, Rio de Janeiro, 2007, pag. 42 (grifos mantidos). A divisão aristotélica entre direito natural e positivo não admitia a extensão do conceito aos animais, muito menos fazia referência à natureza enquanto legisladora. a manumissão, bem como se desconheceria a servidão. Mas depois que a servidão se iniciou pelo direito das gentes, seguiu-se o benefício da manumissão. E como por um único nome natural seríamos chamados 'homens', por direito das gentes começamos a ser de três gêneros: os livres, os servos (a aqueles contrário) e, como terceiro gênero, os libertos, isto é, os que deixaram de ser servos. ${ }^{63}$

É importante ressaltar o reconhecimento, pelo jurisconsulto, de que o status natural do homem era a liberdade, e que a escravidão não se deve ao direito natural, mas ao ius gentium. Este último parece surgir em conjunto com a atuação humana na história. Enquanto, na época primitiva, homens e animais se guiariam pelas regras da natureza com as quais vieram ao mundo, as condutas dos homens criaram novas situações, com base nas quais nasceu o ius gentium. Esse direito dos povos adquiriu tamanha autonomia que Ulpiano pode notar sem qualquer ânimo de crítica a oposição entre o aparato jurídico da escravidão (com seu apêndice, a manumissão) e a igual liberdade de que todo ser humano desfrutaria pelo direito natural. O ius gentium aparentemente derrogou tal disposição ${ }^{64}$. A tripartição do direito em Ulpiano parece confirmar-se em outra citação no mesmo livro do Digesto:

Ius civile é o que não se afasta no todo do direito
natural ou do direito das gentes, bem como não
serve a este em todas as coisas. Assim, quando
acrescentamos ou subtraímos algo do direito
comum, tornamo-lo um direito próprio, isto é, um
direito civil. ${ }^{65}$

A mesma ideia do ius gentium aparece em Hermogeniano, que não é citado pelo Doutor Angélico, mas sem dúvida foi lido por este, dado que trechos de sua obra se intercalam com os de Ulpiano e Gaio no Digesto. Agora o direito das gentes exibe um aspecto mais institucional:

Por este direito das gentes as guerras foram introduzidas, destacados os povos, fundados os reinos, distintos os domínios, postos os limites nos campos, construídos os edifícios, instituídos

63 JUSTINIANO I (org.). Digesto de Justiniano, livro I. Tradução de Hélcio Maciel França Madeira, $2^{a}$ ed. São Paulo: Revista dos Tribunais; Osasco: UNIFIEO, 2000, I.1.4. (Grifos mantidos.)

64 "Being practically inclined, the Romans paid little attention to theoretical underpinnings of this debate and to the ius naturale. Instead, stressing law rather than theory, Roman lawyers rarely discussed the origins of slavery but rather accepted the fact that slavery existed and developed a body of law applicable to slaves and slave owners." MULDOON, James. Spiritual Freedom - Physical Slavery: The Medieval Church and Slavery. In: Ave Maria Law Review, vol. 3, Spring 2005, pag. 75.

65 JUSTINIANO I (org.). Digesto de Justiniano, livro I. Tradução de Hélcio Maciel França Madeira, $2^{\mathrm{a}}$ ed. São Paulo: Revista dos Tribunais; Osasco: UNIFIEO, 2000, I.1.6. (Grifos mantidos.) 
o comércio, as compras e vendas, as locações e as obrigações; excetuadas outras coisas que foram introduzidas pelo ius civile. ${ }^{66}$

Trata-se de um direito que estabelece uma base comum entre os costumes dos vários povos conhecidos pelos romanos. Partindo desse denominador mínimo, as nações desenvolvem seus institutos jurídicos autonomamente, e se estabelecem distinções, como apontado por Gaio em trecho copiado pelo Aquinate:

Todos os povos que são regidos por leis ou por
costumes se utilizam em parte do seu próprio
direito, em parte do direito comum a todos os
homens. Pois o direito que cada povo por si mesmo
a si constituiu este é próprio da mesma civitas e
se chama ius civile, como que um direito próprio
desta mesma civitas. Mas aquele que a razão natural
constituiu entre todos os homens, o qual entre
todos igualmente é protegido, chama-se direito das
gentes, como que o direito do qual todos os povos
se utilizam. ${ }^{67}$

É interessante notar que Gaio não menciona, explicitamente, as palavras "ius naturale", provavelmente atribuindo ao ius gentium o lugar de direito instituído pela razão ${ }^{68}$. Seu direito das gentes equivale, pois, ao direito natural ${ }^{69}$.

Dessa breve incursão pelo tratamento do direito das gentes entre os romanos, tem-se que este parece opor-se em regra ao direito civil, entendido como o ius da cidade. O direito dos povos seria um substrato, em parte filosófico e em parte descoberto por observação, que permitiria uma comunicação jurídica mínima com os povos vizinhos de Roma $^{70}$. Sua origem seria dúplice, em

66 JUSTINIANO I (org.). Digesto de Justiniano, livro I. Tradução de Hélcio Maciel França Madeira, $2^{a}$ ed. São Paulo: Revista dos Tribunais; Osasco: UNIFIEO, 2000, I.1.5. (Grifos mantidos.) 67 JUSTINIANO I (org.). Digesto de Justiniano, livro I. Tradução de Hélcio Maciel França Madeira, $2^{a}$ ed. São Paulo: Revista dos Tribunais; Osasco: UNIFIEO, 2000, I.1.9. (Grifos mantidos.) 68 "Gaius paraît suivre ici une tendance amorcée deux siècles plus tôt, dès l'époque de Cicéron, et qui, s'écartant du point de vue technique des jurisconsultes, prêtait au ius gentium les traits d'un droit valable non plus seulement à Rome, mais chez tous les peuples, comme son nom semblait l'indiquer. Cet usage, sans doute à la fois populaire et pseudo-philosophique, a pu suggérer par la suite qu'on avait affaire à un droit tirant sa validité d'une nécessité supérieure, de la nature même des choses." HAGGENMACHER, Peter. Grotius et la doctrine de la guerre juste. 1983. Tese (Doutorado) - Institut Universitaire de Hautes Études Internationales, Genebra, pag. 315.

69 Note-se que é um direito vigente entre homens, não entre nações tomadas como sujeitos autônomos. Cf. MACEDO, Paulo Emílio Vauthier Borges de. O mito de Francisco de Vitória: defensor dos direitos dos índios ou patriota espanhol? Revista de Direito Internacional, Brasília, v. 9, n. 1, p. 1-13, jan./jun. 2012, pag. 3.

70 HAGGENMACHER, Peter. Grotius et la doctrine de la guerre juste. 1983. Tese (Doutorado) - Institut Universitaire de parte deduzida de postulados racionais e, de outro lado, da certeza da correção de certas práticas que eram disseminadas entre as "gentes" conhecidas. Embora seja relativamente fácil distinguir entre o direito civil e o dos povos, os juristas tropeçavam à hora de separar entre direito das gentes e direito natural - e alguns sequer procuravam distingui-los, como Gaio.

É possível adicionar ou tirar algo desse "direito comum" que parece conter o natural e o das gentes, mas a modificação contará apenas como ius civile. Logo, aqueles dois são imutáveis, ao contrário dos preceitos das cidades. A qualificação de direito comum denota uma observação dos outros povos em busca de confirmação do que se pensa pertencer ao ius gentium. Moreira Alves entende que os direitos da natureza e dos povos compartilham a característica da universalidade, diferindo por ser o primeiro um conceito filosófico provindo do estoicismo, e o segundo o resultado da repetição de costumes entre os povos ${ }^{71}$.

Por fim, um rápido exame da prática romana ajudará a elucidar esse conceito. O ius gentium foi concebido para incluir os estrangeiros presentes em territórios dominados por Roma nas soluções do direito romano sem, contudo, ferir a exclusividade da qual os cidadãos, por tradição e preceitos religiosos, gozavam em relação ao ius civile. Como o procedimento civil na República valorizava sobremaneira o ritual e as fórmulas ditas corretamente, os estrangeiros se viam em dificuldades quando tentavam resolver seus litígios pela via jurídica, dado que não eram admitidos aos processos do direito civil $^{72}$. Para satisfazer esses habitantes, instituiu-se o cargo do pretor peregrino, que ficava a cargo de organizar a resolução judicial das questões envolvendo estrangeiros. Para isso, podiam-se copiar algumas das regras das ações civis, adaptando-as às necessidades locais. Os pretores peregrinos evitavam impor o ius civile a não cidadãos, e passaram a desenvolver um direito próprio para estrangeiros em Roma com base nos costumes mais evidentes que se repetiam entre os povos conhecidos. Foi este o surgimento do ius gentium ${ }^{73}$ que, com a concessão da cidadania romana a todos os habitantes do Império

Hautes Études Internationales, Genebra, pag. 318.

71 ALVES, José Carlos Moreira. Direito Romano, vol. I, $13^{\mathrm{a}}$ ed. Rio de Janeiro: Forense, 2003, pag. 80.

72 VILLEY, Michel. Direito Romano. Porto: Res, 1991.

73 GIORDANI, Mário Curtis. Iniciação ao direito romano, $2^{\mathrm{a}}$ ed. Rio de Janeiro: Lumen Juris, 1991, pags. 84-90. MARKY, Thomas. Curso elementar de Direito Romano, $8^{\mathrm{a}}$ ed. São Paulo: Saraiva, 2007, pag. 15. 
em 212, passou a concentrar-se, exclusivamente, na moderação e evolução do ius civile $e^{74}$ por uma perspectiva cosmopolita ${ }^{75}$.

Tudo isso pode ter influenciado o pensamento do Aquinate ao tratar do direito das gentes. Embora não mencione mais os estrangeiros, seu ius gentium se constitui da observação daquilo em que "todos os homens estão de acordo" 76 , bem como das deduções da lei natural. Embora os exemplos da Suma sejam todos próximos ao direito natural, nos Comentários à Ética, ele cita os "juristas" - provavelmente os que se acabou de discutir - e se mostra bastante consciente da dimensão intercomunitária do direito das gentes: "é regra do direito das gentes as propostas [sic] de que os pactos devem ser cumpridos, e de que as legações são imunes e protegidas, mesmo entre inimigos" $" 77$.

Isso reflete a origem dúplice vista no direito romano, bem como o dilema que os jurisconsultos já haviam enfrentado: o direito das gentes obriga porque é adotado por todos os povos, ou sua aceitação geral é decorrência de sua obrigatoriedade? A resposta de Tomás parece inclinar-se para a primeira opção. $\mathrm{O}$ direito das gentes necessita, essencialmente, do direcionamento da vontade humana, embora de um modo pouco consciente e dócil aos impulsos básicos da lei natural, de modo que todos concordem facilmente com ele ${ }^{78}$, sem necessitar ser promulgado como uma lei civil $^{79}$. Sua popularidade em diversos lugares é um indício de sua adequação à lei natural ${ }^{80}$.

74 SHERMAN, Gordon E. Jus Gentium and International Law. In: The American Journal of International Law, vol. 12, n. 1 (jan. 1918), pag. 60.

75 NUSSBAUM, Arthur. The Significance of Roman Law in the History of International Law. In: University of Pennsylvania Law Review, vol. 100 (1952), pag. 682. VIOLA, Francesco. Derecho de gentes antiguo y contemporâneo. In: Persona y derecho 51 (2004), pags. $167-170$.

76 ST II-II q. 57 a. 3 obj. 1.

77 AQUINO, Santo Tomás de. Da Justiça. (Título original: "Sententia libri Ethicorum, Liber 5".) Tradução de Tiago Tondinelli. Campinas: Vide Editorial, 2012, Lição XII.

78 ST I-II q. 95 a. 4 ad 1.

79 ST II-II q. 57 a. 3 ad 3.

80 "The natural law is absolutely necessary, an evident principle or a necessary conclusion. The law of nations is hypothetically necessary, a conclusion of the greatest fittingness. Positive law is hypothetical, by circumstantial determination." AGUILAR, José Manuel de. The Law of Nations and the Salamanca School of Theology. In: Thomist, vol. 9 (1946), pag. 201. Apud SCHALL, James V. Natural Law and the Law of Nations: Some Theoretical Considerations. In: Fordham International Law Journal, vol. 15, n. 4, 1991, pag. 1024.
Até aqui, nota-se que a concepção tomista do ius gentium conseguiu incorporar o entendimento romano a sua própria teoria jurídica. Esta última, porém, como sabido, não é uma criação original do Aquinate, tendo sido desenvolvida com base na clássica reflexão aristotélica. Embora os conceitos básicos trabalhados pelo Estagirita já tenham sido analisados nas páginas anteriores, vale a pena deter-se em uma das noções mais importantes para a visão aristotélica do direito: a ideia de proporcionalidade.

\section{O IUS GENTIUM NO CONTEXTO do RACIOCÍNIO JURÍDICO ARISTOTÉLICO: A PROPORCIONALIDADE}

Embora não seja explicitada nas passagens estudadas de Tomás de Aquino, a proporcionalidade aristotélica, que será estudada nesta seção, confere sentido e unidade a todas as suas reflexões sobre o tema.

Como já se viu, o Aquinate se detém na conclusão de que o ius gentium é um primeiro consenso entre os povos. Seria fácil concluir, porém, que um consenso tão amplo dificilmente poderá abranger uma grande diversidade de conteúdo. Por outro lado, já se viu que não há confusão com a lei natural; tratam-se de coisas distintas. A primeira parte da chave parece estar no método empregado pelos romanos: no direito das gentes, os vários povos conhecidos concordam. Em segundo lugar, pode-se considerar o modo aristotélico de investigação do direito: este é, antes de mais nada, uma proporção ${ }^{81}$. Entre vários povos com leis díspares entre si, o modo de obter o mesmo ius gentium deve ser observando as condições mais básicas de cada sociedade. Da mesma forma que uma fração pode manter a proporção original alterando seu denominador, desde que o numerador mude na mesma razão, assim também o direito das gentes equivalerá ao mínimo denominador comum que pode haver entre nações conhecidas, desde que se mantenha a igualdade nas relações envolvendo coisas ${ }^{82}$.

Trata-se daquilo que é adequado à convivência humana considerando-se as características mais genéricas

81 ARISTÓTELES. Ética a Nicômaco. Tradução do grego de António de Castro Caeiro. São Paulo: Atlas, 2009, Livro V, III, 1131 b 15 .

82 A analogia entre o direito e a proporcionalidade matemática também é de Aristóteles. Cf. ARISTÓTELES. Ética a Nicômaco. Tradução do grego de António de Castro Caeiro. São Paulo: Atlas, 2009, Livro V, III, 1131 a 30 et seq. 
da sociedade, que podem ser descritas como escolhas inconscientes feitas pelos povos ao longo de suas histórias. Dessa forma, o requisito da vontade humana se faz presente, mesmo que de modo inconsciente e generalizador, como uma "vontade histórica da coletividade". Somente assim a descrição tomista do direito encontrado a partir da consideração das consequências das coisas, que também é o direito estabelecido pelas primeiras conclusões derivadas da lei natural, faz sentido.

Com efeito, quando trata do modo em que a lei humana há de ser derivada da lei natural, a Suma aproveita uma passagem de Isidoro de Sevilha para enumerar as qualidades da norma: "Será a lei honesta, justa, possível segundo a natureza, segundo o costume da pátria, conveniente ao tempo e ao lugar, necessária, útil..." ${ }^{\text {c3 }}$ Ao explicar a fórmula isidoriana, Tomás escreve que a lei não deve, apenas, conformar-se aos costumes do país, mas também às "devidas circunstâncias", mencionando a adequação a tempo e lugar ${ }^{84}$. Tudo isso é dito conveniente para a disciplina que a norma deverá exercer sobre a comunidade. Ou seja, para que possa obrigar com eficácia, a lei positiva humana precisa ajustar-se a certos padrões sociais pré-existentes, os quais dependem das condições de tempo e lugar. Esses padrões sociais constituem o direito das gentes.

Mas o Aquinate não menciona a expressão "ius gentium" neste artigo - identificar as circunstâncias de tempo e lugar que ele menciona ali com o direito dos povos seria forçar seu pensamento? $\mathrm{Na}$ verdade, caso se considerem todos os requisitos exigidos por Tomás para a instituição de uma lei positiva, parece evidente que os costumes e as condições temporais e locais fazem parte do direito das gentes. A grande preocupação do Tratado da Lei é com a dedução das leis inferiores a partir da lei natural. Ao examinar a enumeração das qualidades da lei positiva feita por Isidoro, Aquino anota que a boa lei deve ser conforme à lei divina, à lei natural e à utilidade humana. O respeito aos costumes já existentes e às condições físicas em que o povo vive é ordenado ao segundo tópico, a lei natural. São modos de garantir o respeito à lei natural. E dependem da conduta humana. Uma concretização da lei natural mediante influência da matéria humana é exatamente a ideia de ius gentium que Tomás de Aquino empregava.

O direito das gentes tomista é, então, formado pela

83 ST I-II q. 95 a. 3.

84 ST I-II q. 95 a. 3 c. adequação entre a forma geral de existência de uma sociedade, por um lado, e a convivência humana de forma que possibilite a dar a cada um o seu nas disputas envolvendo bens, por outro. Esses requisitos mínimos necessários ao desenvolvimento do direito civil em cada comunidade constituem o direito dos povos. Em sua caminhada pela história, cada povo faz algumas escolhas, alterando sua situação original ${ }^{85}$. O modo em que tais escolhas são feitas não importa muito, pois o direito se prende, objetivamente, ao panorama externo. $\mathrm{O}$ fato é que cada comunidade humana se encontra em uma condição determinada, apresentando fatores que se repetirão em diversas outras, embora não necessariamente em todas ${ }^{86}$.

Não é difícil enxergar aqui um paralelo com o estudo que Aristóteles faz das polis de seu tempo na Politica. Ali, o filósofo se ocupou sobretudo de catalogar a estrutura e os costumes políticos de aproximadamente uma centena de cidades-estado, buscando confirmação de diversas teses políticas, como as de Platão, através da prática social. Comentando tal obra, Michel Villey diz que é quase um tratado de direito natural — no sentido aristotélico ${ }^{87}$. Aparentemente, o Estagirita deu os primeiros contornos concretos a suas ideias jusnaturalistas da Ética a Nicômaco.

É nesse sentido que o conteúdo do ius gentium tomista não possui, necessariamente, abrangência universal, podendo variar entre sociedades muito distantes e distintas entre si. Em uma das raras vezes nas quais menciona um exemplo de direito das gentes, Tomás de Aquino indica a escravização dos prisioneiros na guerra, afirmando que foi instituída por uma lei humana, sendo também um direito do qual quase todos os povos se valem $^{88}$. Não exige, pois, a unanimidade. Sua adequa-

85 OLGIATI, Francesco. El concepto de juridicidad en Santo Tomás de Aquino. Pamplona: EUNSA, 1977, pag. 253.

86 Embora valha a advertência de James Schall no sentido de que as culturas humanas não são reciprocamente incomensuráveis, exibindo um fundo de discurso comum sobre o que é a natureza humana. SCHALL, James V. Natural Law and the Law of Nations: Some Theoretical Considerations. In: Fordham International Law Journal, vol. 15, n. 4, 1991, pags. 1025-1026.

87 VILLEY, Filosofia, pag. 361.

88 "There is also a kind of slave or servitude by buman law. For law declares that war captives are slaves of the victors, and almost all peoples observe it, and so also we call it a common law of peoples." AQUINAS, Thomas. Commentary on Aristotle's Politics. Versão para o inglês de Richard J. Regan. Indianapolis; Cambridge: Hackett, c2007, I, 4, 1. Vale notar que a tradução inglesa utilizou a mesma palavra "law" para o que Tomás denominara alternativamente "lex" e "ius". O original reza: "Sed etiam est aliquis servus vel serviens secundum legem inter homines posi- 
ção a certo tipo de guerra, de condições sociais e de relações político-religiosas na Antiguidade e na Idade Média, pode ser discutida e possivelmente aceita, enquanto, aplicada aos padrões de convivência do século XXI, seria uma desproporcionalidade clara.

Também se nota a diversidade de origens do direito das gentes, manifestado em cada povo de forma distinta. Alguns usam leges, como as regulações canônicas sobre o direito da guerra em vigor na Cristandade. Outros apenas praticam o ius, que lhes vêm do costume imemorial ou é descoberto na prática ${ }^{89}$. Seja como for, o direito das gentes, embora amplo em seu raio de incidência, não exibe a universalidade da lei natural.

A cada configuração geral de sociedade corresponderão algumas exigências iniciais para que se possa manter a proporção entre pessoas e bens. $\mathrm{O}$ direito das gentes variará, então, de acordo com questões mais básicas como o fato de a sociedade em questão ser grande ou pequena; nômade ou sedentária; aberta ao exterior ou fechada; individualista ou coletivista; estática ou dinâmica... A partir da resposta a estas perguntas iniciais poder-se-á refinar o exame das instituições daquela sociedade na resolução dos casos em que as partes reclamam justiça ${ }^{90}$.

tam. Est enim quaedam promulgatio legis ut illi qui sunt victi in bello, dicantur esse servi eorum, qui contra eos praevaluerunt: et hoc iure quasi omnes gentes utuntur, unde et ius gentium nominatur." AQUINO, Sancti Thomae de. Sententia libri Politicorum. Ed. Leonina, 1971. Disponível em: < http://www.corpusthomisticum.org/cpo.html\#79140 >, acesso em: 01.09.2018. Grifos acrescentados.

89 "Uma proporção justa [...] uma justiça está integrada na cidade de Atenas, não sem dúvida tal como é de fato em cada momento de sua história, mas tal como tende a tornar-se." VILLEY, Michel. Filosofia pag. 359

90 "Is it by law of nature that things are owned privately, within certain limits, under the common circumstances of civilized life? It is. But notice that the statement is not particularly sharp: 'within certain limits' and 'under common circumstances of civilized life.' In a very small tribe in a tropical forest, for instance, in the Amazon or Equatorial Africa, what meaning does private property assume? Are those common conditions realized which are needed in order that it be naturally right that there be some sort and some amount of private property? Perbaps not. Circumstances are conceivable in which doing without private property is the thing good and desirable and right, for the obvious reason that the common forms of civilization which make private property desirable are not realized. Wherever the normal conditions of civilized existence are realized it is right by nature, given those conditions, that there be some sort and some amount of private ownership. Do not try to obtain more precision, more specification, by way of logical connection. It will not work." Embora sem compartilhar da noção de "vida civilizada" do autor, pensa-se que este parágrafo descreve adequadamente a diferença dos resultados que os vários povos do mundo alcançarão ao longo de sua história no que tange ao direito das gentes. SIMON, Yves R. The Tradition of Natural Law: A Philosopher's Reflections. Editado por Vukan Kuic. Nova York: Fordham University Press, 1992, pag. 154.

\section{OUtRAS INTERPRETAÇÕES dO IUS GENTIUM EM Tomás de Aquino}

Essa interpretação do ius gentium tomista não é vista nos principais comentaristas do mestre italiano que analisaram mais a fundo o aspecto jurídico de sua obra. Não obstante, pensa-se que é a mais adequada, pelo que se expôs acima, e pelas insuficiências encontradas em outros esquemas interpretativos, que serão expostos a seguir, para auxiliar a desbastar tal conceito com o rigor do contraditório.

\subsection{Santiago Ramírez}

Em primeiro lugar, Santiago María Ramírez entende o direito das gentes tomista como o direito natural secundário, derivado do primário por via de conclusões imediatas e necessárias ${ }^{91}$. É um direito racional, pois obtido através do uso da razão, embora baste um emprego breve desta para convencer-se da correção de tal direito. Nessa capacidade, contrapõe-se ao direito natural, o qual o autor chama de direito intelectual, convindo ao homem enquanto ser capaz de conhecimento imediato e intuitivo ${ }^{92}$. Para Ramírez, então, o direito natural consiste nos princípios enunciados pela sindérese, sentido interior que possibilita o conhecimento intuitivo a partir do que se percebe na realidade exterior ${ }^{93}$. Esses princípios, que ele resume nos postulados da lei natural do Aquinate ${ }^{94}$, possuem validade universal, são conhecidos por todos e imutáveis ${ }^{95}$. Com base neles, as pessoas podem fazer um esforço dedutivo, consideran-

91 RAMÍREZ, Santiago Maria. El derecho de gentes o natural en Santo Tomás de Aquino (1225-1274). Editado por Carlos Rubén Terceiro-Muiños. San Luis: Universidad Católica de Cuyo, 2007, pags. 40 et seq.

92 RAMÍREZ, Santiago Maria. El derecho de gentes o natural en Santo Tomás de Aquino (1225-1274). Editado por Carlos Rubén Terceiro-Muiños. San Luis: Universidad Católica de Cuyo, 2007, pag. 57.

93 RAMÍREZ, Santiago Maria. El derecho de gentes o natural en Santo Tomás de Aquino (1225-1274). Editado por Carlos Rubén Terceiro-Muiños. San Luis: Universidad Católica de Cuyo, 2007, pag. 28.

94 RAMÍREZ, Santiago Maria. E1 derecho de gentes o natural en Santo Tomás de Aquino (1225-1274). Editado por Carlos Rubén Terceiro-Muiños. San Luis: Universidad Católica de Cuyo, 2007, pag. 13.

95 RAMÍREZ, Santiago Maria. El derecho de gentes o natural en Santo Tomás de Aquino (1225-1274). Editado por Carlos Rubén Terceiro-Muiños. San Luis: Universidad Católica de Cuyo, 2007, pags. $10-11$. 
do a realidade prática na qual estão inseridas, e chegar a novos princípios ${ }^{96}$, nos quais poderão basear-se para criar leis adequadas a cada sociedade. Trata-se de uma razão deliberativa e comparativa, que chega a resultados absolutos $^{97}$ e universalmente válidos ${ }^{98}$ — seus juízos só falham poucas vezes ${ }^{99}$, pela limitação da razão humana. O papel da razão humana na descoberta desse ius gentium é tão restrito, e ele é formado por proposições tão obviamente dedutíveis da lei natural, que se reduz, na verdade, a um direito natural ${ }^{100}$, ou natural racional ${ }^{101}$. Carlos Soria completa esse raciocínio explicando que, nos locais onde Tomás qualifica o ius gentium de positivo, emprega esse adjetivo de modo extensivo, querendo significar, simplesmente, que decorre de um positivo esforço humano para deduzir suas conclusões ${ }^{102}$.

Santiago Ramírez está certo quanto ao papel intermediário do direito das gentes em Tomás de Aquino. Não se pode concordar, porém, acerca da confusão que faz entre direito e lei ${ }^{103}$. Com efeito, para ele o direito

96 RAMÍREZ, Santiago Maria. El derecho de gentes o natural en Santo Tomás de Aquino (1225-1274). Editado por Carlos Rubén Terceiro-Muiños. San Luis: Universidad Católica de Cuyo, 2007, pags. 31-32.

97 RAMÍREZ, Santiago Maria. El derecho de gentes o natural en Santo Tomás de Aquino (1225-1274). Editado por Carlos Rubén Terceiro-Muiños. San Luis: Universidad Católica de Cuyo, 2007, pag. 36.

98 RAMÍREZ, Santiago Maria. El derecho de gentes o natural en Santo Tomás de Aquino (1225-1274). Editado por Carlos Rubén Terceiro-Muiños. San Luis: Universidad Católica de Cuyo, 2007, pag. 49 e 69-79.

99 RAMÍREZ, Santiago Maria. El derecho de gentes o natural en Santo Tomás de Aquino (1225-1274). Editado por Carlos Rubén Terceiro-Muiños. San Luis: Universidad Católica de Cuyo, 2007, pag. 46.

100 RAMÍREZ, Santiago Maria. El derecho de gentes o natural en Santo Tomás de Aquino (1225-1274). Editado por Carlos Rubén Terceiro-Muiños. San Luis: Universidad Católica de Cuyo, 2007, pag. 56.

101 RAMÍREZ, Santiago Maria. El derecho de gentes o natural en Santo Tomás de Aquino (1225-1274). Editado por Carlos Rubén Terceiro-Muiños. San Luis: Universidad Católica de Cuyo, 2007, pag. 58.

102 SORIA, Carlos. Introducción a las cuestiones 95-97. In: AQUINO, Santo Tomás de. Suma Teológica, tomo VI. Madrid: Biblioteca de Autores Cristianos, 1956, pag. 148.

103 "Se comprende sin dificultad por qué el Angélico toma a veces la ley y el derecho como sinónimos, y por qué los divide o distingue proporcionalmente. La ley es esencialmente un produto o una creación de la sindéresis o de la prudência gubernativa en forma de proposiciones imperativas reguladoras de las acciones bumanas al bien comun de toda la humanidad o de porciones determinadas de ella que llamamos Estados - comunidades perfectas -. Porque así como en nuestras actividades exteriores y corporales distinguimos el trabajo y su producto o resultado, por ejemplo, la construcción de una casa y la misma casa construida, asi también en las actividades interiores de nuestra inteligencia especulativa y práctica distinguimos: natural consiste, formalmente, no conteúdo dos enunciados ou princípios da sindérese ${ }^{104}$. Dessa identificação, que não é do Aquinate, como se deve insistir, decorre a descrição que o professor espanhol faz do direito das gentes como uma espécie de direito natural. Caso se entenda o direito como lei, será preciso determinar de qual norma o ius gentium derivará. O próprio nome exclui que seja a lei positiva, de aplicação limitada às fronteiras nacionais. Portanto, necessariamente, derivará da lei natural, e poder-se-ia especificar que é da terceira das inclinações inatas descritas por Tomás de Aquino ${ }^{105}$ (busca pelo bem específico do ser humano através da vida social $\left.{ }^{106}\right)$; daí o posicionamento de Ramírez ${ }^{107}$.

Tal esquema é problemático, porém, em primeiro lugar por olvidar uma distinção capital no pensamento do Doutor Angélico. A lei é, para ele, uma ordenação da razão. E o direito é a proporção igualitária existente entre homens e coisas, ou aquilo que deve ser entregue ao outro em virtude de tal proporção. Já se viu que os dois conceitos coexistem de modo próximo: sem a lei

- el acto mismo de entender o de ordenar y su producto o resultado, que es el verbo mental simple o compuesto procedente y resultante de nuestra inteligencia en acto: verbo mental simple en forma de mero término o definición, correspondiente a la simple aprebension;

- verbo mental compuesto en forma de enunciación o de proposición, correspondiente al juicio inmediato;

- y verbo mental compuesto en forma de silogismo o de argumentación, correspondiente al juicio mediato o discurso.

$Y$ el contenido de ese verbo mental compuesto del entendimiento o de la razón práctica en forma de enunciación o de proposición imperativa, es el derecho objetivo formalmente considerado, o, lo que es lo mismo, el justo medio, el objeto formal de la justicia." RAMÍREZ, Santiago Maria. E1 derecho de gentes o natural en Santo Tomás de Aquino (1225-1274). Editado por Carlos Rubén Terceiro-Muiños. San Luis: Universidad Católica de Cuyo, 2007, pags. 8-9.

104 RAMÍREZ, Santiago Maria. El derecho de gentes o natural en Santo Tomás de Aquino (1225-1274). Editado por Carlos Rubén Terceiro-Muiños. San Luis: Universidad Católica de Cuyo, 2007, pag. 10.

105 MACEDO, Paulo Emílio Vauthier Borges de. Uma comparação entre os conceitos de Jus Gentium em Francisco Suárez e Hugo Grócio. 2007. Tese (Doutorado em direito) - Universidade do Estado do Rio de Janeiro, Rio de Janeiro, 2007, pags. 51-52.

106 ST I-II q. 94 a. 2 c.

107 A confusão entre direito natural e lei natural é bastante comum entre os estudiosos da História do Direito Internacional. Como exemplo, ver VERDROSS, Alfred. O fundamento do direito internacional. Revista de Direito Internacional, Brasília, v. 10, n. 2, 2013. Título original: Le fondement du droit international. Recueil des cours de l'Académie de Droit International, 1927, p. 325-384. Tradução de Marcelo Dias Varella (coordenador), Amábile Pierroti, Luiza Nogueira e Marlon Tomazette. Disponível em: < https:// www.publicacoesacademicas.uniceub.br/rdi/article/view/2685/ pdf >. Acesso em: 01.09.2018, pags. 4 passim. 
será difícil e arbitrário determinar o que é de cada um. Mas o jusnaturalismo de Aquino trata ambos como realidades separadas, pertencentes a gêneros distintos e separados por muitas páginas na Suma Teológica: a lei é um princípio, logo antecede a ação. E o direito é o objeto de uma virtude, logo influi, diretamente, no curso da ação. Portanto, embora o ius gentium realmente ocupe um lugar intermediário, é preciso definir a qual das realidades pertence: lei ou direito. No pensamento do autor espanhol resenhado, isso não fica claro. Parece que Ramírez opta por aproximar o direito das gentes da lei (natural), em consonância com todo o restante do direito, dada a equivalência que enxerga entre os dois termos ${ }^{108}$.

Deve-se questionar qual a utilidade do conceito de ius gentium. Pois o que é decorrência próxima e imediata dos princípios da lei natural compartilha a natureza da instância superior ${ }^{109}$. Afinal, a lei natural pode ser descrita como "racional" no sentido de que é descoberta pelo ser humano no exercício de sua razão (era por isso que os animais não se sujeitavam propriamente à lex naturalis, mas apenas impropriamente e por analogia entre a obediência à lei e o seguimento ao instinto). Embora o Aquinate postule a existência de primeiros princípios inatos que residem desde o início na mente humana, tais princípios não podem ser aplicados fora da realidade, devendo ser transpassados do intelecto especulativo ao prático, no que se requer a faculdade racional. Fica claro então que Ramírez estende em demasia o conceito de ius gentium quando o aplica a toda a lei natural conhecida por via de consequência pelo raciocínio humano. Pouca coisa ficará de fora: tão somente alguns princípios lógicos indemonstráveis e autoevidentes. De outro lado, o autor também atribui ao direito das gentes um caráter

108 A respeito, ver a passagem na qual o autor citado transcreve e traduz um trecho do Tratado da Lei. Enquanto o original reza " $A d$ ius gentium pertinent ea quae derivantur ex lege naturae sicut conclusiones ex principiis", Ramírez verte ao castelhano como "Al derecho de gentes, en efecto, pertenecen las normas que se derivan del derecho natural como las conclusiones de sus princípios". (Grifos acrescentados.) Onde o Aquinate escreveu "lei", seu estudioso do século XX entendeu "direito". Cf. RAMÍREZ, Santiago Maria. El derecho de gentes o natural en Santo Tomás de Aquino (1225-1274). Editado por Carlos Rubén Terceiro-Muiños. San Luis: Universidad Católica de Cuyo, 2007, pag. 41.

109 Por exemplo, na I-II q. 94 a. 4, Tomás indica que pertencem à lei natural não somente os primeiros princípios universais, mas também as conclusões práticas derivadas de tais princípios, que podem falhar excepcionalmente em alguns casos. Porém, ele não menciona a expressão ius gentium em nenhuma parte deste artigo, motivo pelo qual se discorda da interpretação de Ramírez, que enxerga nesse passo uma referência ao caráter natural do direito das gentes. quase intuitivo, descrevendo-o como um direito tão conatural ao homem e conhecido de todos que não haveria necessidade de pô-lo por escrito ${ }^{110}$. Não se entende por completo como diferenciá-lo então da lei natural ${ }^{111}$.

$\mathrm{Na}$ verdade, o direito das gentes é composto por instituições existentes, que são mais concretas que os princípios da lei natural. Como evidenciado pelo conteúdo que os romanos adscreviam ao ius gentium, este repousa em práticas aceitas por vários povos, encontrando-se mais próximo da realidade física que a lei da natureza. Pergunta-se então, como o direito das gentes, na concepção defendida por Ramírez, reagirá a mudanças históricas, sociais, econômicas, demográficas etc. que podem alterar o rol das coisas geralmente aceitas pelos povos.

O exemplo da escravidão é expressivo para o assunto: considerado em Roma como pertencente ao ius gentium, é hoje unanimemente criticado e visto como estranho a qualquer forma de ius. Curiosamente, o professor espanhol não o condena, mencionando que pertenceria ao direito natural especificamente humano, equivalente ao direito das gentes ${ }^{112}$. Apesar de sua opinião em contrário, ele seria hoje claramente minoritário e nem a escravidão nem a servidão gozam do assentimento universal com o qual já contaram. Logo, o direito das gentes modificou-se da Antiguidade ao presente. Já Ramírez aceita, apenas, mudanças em pequena escala em seu ius gentium ${ }^{113}$, relacionadas com a dificuldade que al-

110 RAMÍREZ, Santiago Maria. El derecho de gentes o natural en Santo Tomás de Aquino (1225-1274). Editado por Carlos Rubén Terceiro-Muiños. San Luis: Universidad Católica de Cuyo, 2007, pag. 71.

111 Nesta linha, Luiz Henrique Cascelli de Azevedo interpreta o ius gentium como exibindo apenas diferenças acidentais para com o direito natural "primário". AZEVEDO, Luiz Henrique Cascelli de. Ius Gentium em Francisco de Vitoria: a fundamentação dos Direitos Humanos e do Direito Internacional na tradição tomista. Porto Alegre: Sergio Antonio Fabris, 2008, pag. 141.

112 "Como el derecho de propiedad privada, asi también el derecho de servidumbre del menos hábil y dotado naturalmente al más dotado e inteligente es de derecho natural especificamente bumano o de gentes." RAMÍREZ, Santiago Maria. El derecho de gentes o natural en Santo Tomás de Aquino (1225-1274). Editado por Carlos Rubén Terceiro-Muiños. San Luis: Universidad Católica de Cuyo, 2007, pag. 51.

113 "El [derecho] de gentes es invariable en cuanto a su forma de justicia, pero puede variar y cambiar en algunos casos raros en cuanto a su materia [...] No admite mutación per se, de suerte que deje de ser justo lo que antes to era, sino sólo per accidens en algunos casos excepcionales, por el cambio de las circunstancias. [...] Mutación puramente material y circunstancial, no formal ni essencial..." RAMÍREZ, Santiago Maria. El derecho de gentes o natural en Santo Tomás de Aquino (1225-1274). Editado por Carlos Rubén Terceiro-Muiños. San Luis: Universidad Católica de 
gum caso concreto possa representar à aplicação da lei. Contudo, o exemplo da escravidão e o da propriedade privada dos campos acima descrito ilustram hipóteses em que ocorreu mudança material no direito das gentes, e não apenas um caso singular com alguma especificidade não prevista na lei.

Paulo Emílio de Macedo se detém sobre o exemplo da escravidão, postulando-lhe uma origem ao menos remotamente natural, uma vez que seria um substituto preferível ao massacre dos prisioneiros vencidos em batalha ${ }^{114}$. Durante a época de Tomás de Aquino, o emprego da razão humana de modo condicionado e consecutivo, a partir dos postulados gerais da lei natural, teria alcançado a consagração da escravidão como uma conclusão hipotética, ainda imperfeita ${ }^{115}$. Não há o que objetar a isso, mas deve ser dito que essa derivação do direito natural não parece ser per conclusionem, e sim por determinação: posto que a lei natural proíbe o homicídio de inocentes, cabe aos diferentes povos concretizar tal preceito nas diversas circunstâncias. A escravização do prisioneiro não parece uma conclusão que prescinda de certa deliberação e decisão — marcas da positivação do direito.

Já no tempo de Tomás, a multiplicidade de alternativas sobre o destino do capturado em guerra era visível. Enquanto a escravização ainda era praticada nas fronteiras da Cristandade, especialmente nas lutas contra os árabes e eslavos, as guerras entre os próprios príncipes cristãos na Europa Ocidental não terminavam de forma alguma com a redução dos combatentes vencidos à servidão ${ }^{116}$. No caso de luta contra hereges, estes podiam

Cuyo, 2007, pags. 74-75.

114 "The etymology of servi, slaves, was considered to depend upon servare, to save the lives os prisioners. These often drastic legal consequences of the Roman just war passed almost intact into medieval opinions." RUSSELL, Frederick H. The Just War in the Middle Ages. Cambridge: Cambridge University Press, 1975, pag. 7. As palavras grifadas encontram-se em itálico no original. Essa derivação etimológica é recolhida também por Agostinho de Hipona. Cf. AUGUSTINUS HIPPONENSIS (Santo Agostinho de Hipona). De civitate dei contra paganos libri XXII, Livro XIX, 15. Roma: Città Nuova Editrice, [?]. Disponível em: < http://www.augustinus.it/latino/index.htm >. Acesso em: 01.09.2018.

115 MACEDO, Paulo Emílio Vauthier Borges de. Uma comparação entre os conceitos de Jus Gentium em Francisco Suárez e Hugo Grócio. 2007. Tese (Doutorado em direito) - Universidade do Estado do Rio de Janeiro, Rio de Janeiro, 2007, pags. 51-52.

116 "With the fall of Rome enslavement was gradually limited to European pagans. As Europe became Christian, only non-Europeans could be slaves. [...] In contrast to antiquity, Christian nations had abandoned the principle that all civilian populations or prisoners of war were at the disposal of warring neighbours." DRESCHER, Seymour; FINKELMAN, Paul. Slavery. ser mortos ou expulsos da terra ${ }^{117}$. Durante o empreendimento das Cruzadas, bem conhecido à época, a atitude dos exércitos europeus perante os muçulmanos variou entre aniquilação total do inimigo e estabelecimento de suseranias com a manutenção do convívio entre cristãos e não cristãos ${ }^{118}$. Para o que importa aqui, a aceitação da redução do prisioneiro à condição de escravo pelo Aquinate parece um reconhecimento da conveniência deste expediente em certas situações, mas não uma conclusão extraída a modo de teorema da lei natural.

Considere-se, ainda, que a justificativa tomista para a escravização do prisioneiro de guerra não se encontra na Suma Teológica, mas nos Comentários à Política de Aristóteles, como será visto adiante. Quando menciona a servidão a título de exemplo de instituto do direito das gentes, no Tratado da Justiça, o Aquinate escreve:

Considerando de maneira absoluta, não há razão natural para que este homem seja escravo, mais do que um outro, mas só por uma utilidade consequente, enquanto seja vantajoso a um ser governado por um mais sábio, e a este ser ajudado por aquele [...] Por isso, a escravidão, pertencente ao direito das gentes, é natural no segundo sentido, não no primeiro. ${ }^{119}$

Parte-se da mesma constatação feita pelos romanos: a liberdade é o estado natural do ser humano. Mas, enquanto os jurisconsultos silenciavam sobre a introdução da escravidão pelo ius gentium, permitindo tanto interpretá-la como um acréscimo quanto uma afronta à lei natural, Tomás de Aquino não pode se dar ao luxo de aceitar que sua lex naturalis seja inócua nesse tema. Assim, advoga por uma compatibilidade condicional da escravidão com a lei da natureza: na medida em que representar uma utilidade para senhor e servo, ela não ofenderá a lei da natureza. O ganho do amo estará em ser ajudado pelo servidor, e este se beneficiará da direção mais sábia do senhor.

Para que o leitor contemporâneo possa compreen-

In: FASSBENDER, Bardo; PETERS, Anne (orgs.). The Oxford Handbook of the History of International Law. Oxford: Oxford University Press, 2012, pags. 893-895.

117 RUSSELL, Frederick H. The Just War in the Middle Ages. Cambridge: Cambridge University Press, 1975, pag. 196.

118 WILLIAMS JR., Robert A. The Medieval and Renaissance Originis of the Status of the American Indian in Western Legal Thought. In: Southern California Law Review, n. 57 (1983), pags. 23-24.

119 ST II-II q. 57 a. 3 ad 2. Relembre-se que o "primeiro modo" pelo qual se estabelecia o direito natural dizia respeito à consideração das coisas em si, e o "segundo modo", ao exame das circunstâncias e consequências das condutas. 
der bem o raciocínio tomista nesse passo, são necessários dois esclarecimentos. Em primeiro lugar, o século de Tomás conhecia diversas formas de servidão, desde a escravidão pura e simples reservada aos inimigos do Cristianismo que fossem capturados em batalha, até a habitual vassalagem feudal, dominante nos feudos mas dependente das condições locais para seu detalhamento ${ }^{120}$. Com efeito, a pluralidade do direito medieval constitui uma de suas características definidoras ${ }^{121}$. Perante esse leque de opções, parece certo que o Doutor Angélico, cujas preocupações distavam de análises históricas, faz referência à servidão que conhece e que pode ser reconhecida por seus contemporâneos, não àquela que Ulpiano e seus colegas tinham em mente ${ }^{122}$.

O segundo esclarecimento cinge-se à noção de utilidade empregada aqui pelo mestre de Roccasecca. Como ele deixa claro ao comentar as qualidades da lei positiva segundo Isidoro de Sevilha, útil é aquilo que proporciona o verdadeiro bem, e tanto mais útil ao homem quanto mais se aproximar de sua finalidade última ${ }^{123}$. Não se trata de uma mera conveniência, ao modo da filosofia dos utilitaristas.

Feitas essas advertências, compreende-se que a licitude da servidão, para Tomás, depende de corresponder ao bem do senhor e do servo. O que somente poderá ser aferido caso se examinem todas as circunstâncias que influem na relação específica. Aristóteles recomendava atenção à pessoa do mestre e do escravo, pois haveria indivíduos que nasceram para servir e outros naturalmente dispostos ao domínio. Essa postura não se sustenta diante do paradigma cristão no qual o Aquinate

120 A tradução espanhola do trecho acima transcrito equipara "servitus" a "servitud", e não a "esclavitud".

121 "O particularismo jurídico do primeiro período medieval, ou seja, a extrema fragmentação até mesmo espacial do direito, justifica-se nessa incontrolada exuberância consuetudinária. Sem um controle do alto, cada coisa - entendendo-se por 'coisa' não uma res mobilis efêmera, mas uma realidade fundiária dotada de força incisiva própria no tecido socioeconômico — tende a exprimir sua normativa, a se diferenciar e a se particularizar. As fontes falam à exaustão de consuetudo regionis, consuetudo loci, consuetudo terrae, consuetudo fundi, consuetudo casae, quase a nos mostrar que os usos, inscritos na terra com trama muito ramificada, chegam a isolar não apenas uma região, mas até mesmo uma empresa agrária da outra: cada terra, cada unidade agrária almeja uma norma própria." GROSSI, Paolo. A ordem jurídica medieval. São Paulo: Martins Fontes, 2014, pag. 118.

122 AUBERT, Jean-Marie. Le droit romain dans l'oeuvre de Saint Thomas. Paris: J. Vrin, 1955, pag. 113. URDÁNOZ, Teofilo. Introducción a la cuestión 57. In: AQUINO, Santo Tomás de. Suma Teológica, tomo VIII. Madrid: Biblioteca de Autores Cristianos, 1956, pag. 229.

123 ST I-II q. 95 a. $3 c$. estuda, que atribui ao ser racional uma dignidade superior $^{124}$. Portanto, a servidão somente pode ser justificada por circunstâncias externas ao indivíduo ou situações criadas pela conduta humana. No caso do prisioneiro, a guerra criava um estado no qual a escravização poderia ser uma resposta adequada (embora não fosse a única possível à época de Tomás, insista-se). No que tange ao servo, circunstâncias históricas podem realmente ter contribuído para tornar a servidão proporcional ao bem comum e ao bem individual dos envolvidos naquele tempo, como uma "razão consequente". Então, o exemplo da licitude da servidão feudal, classificada explicitamente por Aquino como de direito das gentes, revela que este direito é estabelecido com atenção tanto à lei natural — de onde se origina — quanto aos "costumes sociais", às "devidas circunstâncias" e aos "lugares e tempos", ordenando-se ao bem comum ${ }^{125}$ da sociedade em que vigorará.

Compare-se este exemplo com o de uma simples derivação da lei natural a modo de conclusão: "pertencem ao direito das gentes aquelas coisas que derivam da lei da natureza como as conclusões dos princípios, como as compras justas, as vendas, e outras coisas semelhantes, sem as quais os homens não podem conviver uns com os outros" ${ }^{\prime 26}$. Havendo uma relação de troca, seja na forma de escambo, seja monetarizada, é imediatamente dedutível que a transação deve ser justa e que nenhum dos partícipes pode fraudar o outro. Trata-se de uma conclusão direta dos princípios da lei natural como o da igualdade, da verdade e da sociabilidade humana. Essa conclusão vale em todo e qualquer caso em que haja alguma troca, independentemente da cultura e especificidades locais. É evidente que nem todas as formas de vida social desenvolvem o hábito da permuta. Porém, uma vez que se decida trocar qualquer objeto por outro, a lei natural imporá a igualdade nas prestações e a honestidade, sem importar de qual bem se trata. Pois aqui se fala em uma conclusão, isto é, uma determinação alcançada unicamente com base no conhecimento inato da lei natural. Pode-se compará-la à subsunção de um fato (a compra) a uma norma (as partes da lei natural que revelam a igualdade entre todos etc.).

Não parece que a mesma evidência indique que um soldado vencido deva ser escravizado, nem que alguma

\footnotetext{
124 ST I q. 29 a. 1 e a. 3.

125 ST I-II q. 95 a. $3 c$.

126 ST I-II q. 95 a. 4 c
} 
pessoa deva assumir a função de servo. Nesses casos, a solução somente poderá ser alcançada mediante a introdução de um terceiro termo: a consideração das circunstâncias sociais. A lei natural não impõe algum tipo de tratamento específico ao inimigo (embora vede crueldades desnecessárias), nem uma forma exata de relação de trabalho entre homens (embora vede o predomínio da força, as vexações etc.). Em determinadas sociedades (como aquela em que viveu Tomás de Aquino - daí os exemplos -), tais tratamentos contribuirão para alcançar soluções relativamente igualitárias ou justas. Em outras (como a dos povos nômades, por exemplo), essas soluções, possivelmente, não seriam adequadas.

Uma última discordância em relação a Ramírez diz respeito ao papel atribuído à vontade humana na formulação do direito das gentes. $\mathrm{O}$ autor ibérico não exige muito das pessoas para que logrem compreender tal direito: basta seguir o que é óbvio, evidente, considerando a realidade com base nas inclinações inatas da lei natural. Em contraste, defende-se que, de acordo com o Aquinate, o direito das gentes se constitui com base na proporção entre as condições mais básicas das sociedades e a manutenção da igualdade de valor entre as pessoas. Nessa toada, a vontade humana ganha relevo, embora não considerada de modo singular, e sim em sua tarefa de moldar a sociedade através da História, formando as características principais que distinguirão o modo de vida ali. Para Ramírez, a principal contribuição do homem para o direito das gentes está em descobri-lo na realidade obedecendo aos postulados da lei natural. Ao contrário, as pessoas possuem uma função propriamente criadora em relação ao ius gentium, muito embora relativamente inconsciente. A "consideração das coisas em função de suas consequências" do teólogo medieval remete à deliberação e discussão humanas acerca da maior ou menor conveniência de adotar determinado instituto. No âmbito do ius gentium, tais deliberação e discussão ocorrem de modo disperso em cada sociedade, podendo perdurar por várias gerações, até que o instituto seja definitivamente aceito. Mas se trata sempre de uma razão deliberativa em busca de consenso, razão pela qual o direito das gentes possui um grau de positividade maior que o preconizado por Santiago María Ramírez. Em outras palavras: o direito das gentes não se modifica, apenas, a modo de correção, como se os povos gradativamente adquirissem uma "melhor" compreensão sobre o mesmo. Ele se modifica de acordo com as sociedades que o utilizam.

\subsection{Peter Haggenmacher}

Peter Haggenmacher, por sua vez, apresenta o ius gentium tomista como um conceito equívoco, fruto da tentativa do teólogo medieval de elaborar uma interpretação coerente a partir dos textos dos jurisconsultos romanos, que enfatizavam a ligação com o direito natural, e de Santo Isidoro de Sevilha, que parece favorecer o direito positivo ${ }^{127}$. Tomás também precisou vencer a dificuldade adicional de não encontrar ajuda em Aristóteles, que omite o direito das gentes ${ }^{128}$. Segundo Haggenmacher, a saída foi dividir a exposição do ius gentium pelas duas seções da Pars Secunda, aprofundando-se na relação com o direito natural no Tratado da Justiça, e com o direito positivo no Tratado da Lei. Dessa forma, o direito dos povos na Suma Teológica é dual, por compreender as duas noções tradicionais, de um direito superior por um lado, e consensual por outro; mas equívoco, por ser comum à humanidade, mas distinguir-se do direito natural, e por ter natureza parcialmente positiva, porém sem provir de um ato legislativo. Para o professor húngaro, a solução tomista atribuía a positividade do ius gentium a uma pseudolegislação e um pseudo consentimento de todas as comunidades humanas informadas pela razão natural, solução qualificada de insuficiente ${ }^{129}$.

Reconhece-se a Haggenmacher o mérito de evidenciar as influências dúplices que agiram sobre o autor da Suma, incluindo o conhecimento que o teólogo tinha da jurisprudência romana. Porém, embora seja certo que as duas partes da Secunda da Suma exibam conteúdos bastante distintos, não se pode dizer que o ius gentium de uma é radicalmente oposto ao da outra. Insiste-se em que o Doutor Angélico enfatizou aspectos diferentes do direito dos povos em cada momento. A falta de clareza que surge quando se analisam os dois trechos concomitantemente pode ser consequência de se atribuir ao mestre de Roccasecca uma intenção que não era sua, como faz Haggenmacher ao ponderar que o motivo para o ius gentium aparecer em duas passagens separadas era a vontade de Tomás de dar coerência a

127 HAGGENMACHER, Peter. Grotius et la doctrine de la guerre juste. 1983. Tese (Doutorado) - Institut Universitaire de Hautes Études Internationales, Genebra, pag. 330.

128 HAGGENMACHER, Peter. Grotius et la doctrine de la guerre juste. 1983. Tese (Doutorado) - Institut Universitaire de Hautes Études Internationales, Genebra, pag. 327.

129 HAGGENMACHER, Peter. Grotius et la doctrine de la guerre juste. 1983. Tese (Doutorado) - Institut Universitaire de Hautes Études Internationales, Genebra, pag. 330. 
duas tradições divergentes sobre o tema ${ }^{130}$. Isto parece contestável, quando se nota que o método em geral empregado na Suma não é este. A confirmar-se a hipótese metodológica de Haggenmacher, haveria no Aquinate uma preocupação específica com o conceito do direito das gentes, seus limites e suas aplicações. Mas faltam evidências de um tal enfoque por Tomás, que costuma reservar ao menos uma questão ou artigo para definir termos importantes que ele voltará a empregar em sua exposição teológica. Com o direito das gentes, isto não ocorre. Ele é mencionado, primeiramente, entre outras marcas típicas da divisão isidoriana da lei ${ }^{131}$, e, posteriormente, mesmo figurando na epígrafe do artigo, apenas como uma das maneiras de encontrar o direito natural, que é o verdadeiro objeto da investigação naquele pas$\mathrm{so}^{132}$. É duvidoso que Aquino tencionasse estudar o ius gentium em si; parece que ele tropeçou com o conceito ao tratar da universalidade da lei natural, no Tratado da $L e i$; e ao esclarecer o que entendia por direito natural, no Tratado da Justiça. É por isso que não se preocupa em defini-lo taxativamente; e o termo é relegado a ser compreendido através do contraste com conceitos "fortes": lei positiva, lei natural e direito natural.

Embora o autor resenhado mencione a diferença atribuída por Tomás de Aquino entre direito natural e positivo, por uma parte, e lei natural e positiva, por ou$\operatorname{tra}^{133}$, tal dissociação não produz efeito em sua interpretação do ius gentium tomista - daí apontar equivocidade no autor da Suma. Ora, o direito das gentes em Santo Tomás nada mais é que a primeira concretização dos postulados abstratos e genéricos da lei natural. Enquanto estes têm validade universal, referindo-se ao que o homem pode captar do modo como Deus governa o cosmos, e variabilidade pequena, explicável apenas por falhas na apreensão humana da natureza das coisas; o direito das gentes representa o encontro inicial desses

130 "Confrontant les textes romains entre eux, puis avec Aristote et Isidore, il demeure frappé par l'ambigüité du concept et par la multiplicité de ses sens. Pour en sauver l'unicité, il se résout à en diviser l'exposé, ce qui le conduit à l'intégrer dans deux sections différentes de la Secunda." HAGGENMACHER, Peter. Grotius et la doctrine de la guerre juste. 1983. Tese (Doutorado) - Institut Universitaire de Hautes Études Internationales, Genebra, pag. 330. A palavra grifada encontra-se em itálico no original.

131 ST I-II q. 95 a. 4 - "Isidoro estabeleceu convenientemente a divisão das leis humanas?" Das quatro objeções ali discutidas, apenas a primeira menciona o ius gentium.

132 ST II-II q. 57 a. 3.

133 HAgGENMACHER, Peter. Grotius et la doctrine de la guerre juste. 1983. Tese (Doutorado) - Institut Universitaire de Hautes Études Internationales, Genebra, pag. 329. enunciados que expressam regularidades naturais com a realidade concreta, entendida ainda em um sentido amplo, isto é, sem chegar às particularidades de um caso concreto, nem de uma sociedade em particular. Este é o direito das gentes quando estudado a partir do conceito de lei.

Observando-o a partir da noção tomista de direito, que Haggenmacher acertadamente identifica com o justo ou díkaion aristotélico, uma relação objetiva de adequação visando o outro ${ }^{134}$, o direito das gentes ainda é muito impreciso para mostrar exatamente o que deve ser entregue a cada um. Mas se trata de um primeiro limite da atividade jurídica, estabelecido através da materialização do direito natural nas circunstâncias gerais de várias sociedades em contato. É construído por consenso, mas não a modo de um parlamento, e sim pelas marcas estruturais das sociedades, que foram sendo esculpidas e escolhidas pouco a pouco através das diversas gerações que se sucederam levando a vida de certo modo e utilizando certos institutos que acabam gozando de uma aceitação geral. Enquanto iustum, então, o direito das gentes consiste naquilo que se deve a outrem por uma exigência da igualdade determinada por uma proporção entre as instituições mais básicas e populares da sociedade e os bens envolvidos na transação.

Juntando os dois conceitos, nota-se que a ambiguidade observada por alguns no ius gentium de Tomás de Aquino reflete a pluralidade de sentidos da palavra "direito", comentada por e já notada pelo Estagirita ${ }^{135}$. O direito, também, pode ser dito "lei", embora impropriamente ${ }^{136}$. Assim, também, o direito das gentes pode ser entendido como concretizações abstratas da lei natural, as primeiras conclusões estabelecidas por via de simples dedução. Mas, quando se enfatiza a primeira palavra em ius gentium, tratar-se-á de uma etapa na caminhada das sociedades humanas em busca de definir a melhor proporção possível entre pessoas e coisas para atingir o bem comum.

Outra razão da falta de univocidade nessa conceituação do direito dos povos é que, na teoria jurídica do Aquinate, não somente este, mas todo direito é natural e

134 "Rapport objectif d'adéquation, visant non la seule personne de l'agent, comme dans les autres vertus, mais la relation qu'à travers son action il entretient avec autrui." HAGGENMACHER, Peter. Grotius et la doctrine de la guerre juste. 1983. Tese (Doutorado) - Institut Universitaire de Hautes Études Internationales, Genebra, pag. 329.

135 ST II-II q. 57 a. 1 ad 1.

136 ST II-II q. 57 a. 1 ad 2. 
positivo. Embora o mestre de Roccasecca não seja familiar com as hodiernas divisões dos "ramos do direito", seu bom conhecimento do direito romano já o leva a aceitar classificações das leis "segundo a distinção dos estamentos que contribuem especialmente ao bem comum", segundo a forma de governo adotada pelo Estado, e segundo a matéria da qual tratam ${ }^{137}$. Todos esses campos do direito positivo são influenciados pelo direito natural, concretizando-o por meio de determinações e escolhas da comunidade ou simplesmente impondo o respeito ao ius naturale. No vocabulário atual, poder-se-ia afirmar que os direitos civil, penal, constitucional etc. são em parte direito natural e em parte, positivo, pois essa summa divisio refere-se às fontes primeiras do justo, cujas aplicações se manifestarão em todas as áreas das relações humanas envolvendo coisas ${ }^{138}$, áreas essas que serão futuramente aglutinadas em torno dos campos de estudo da ciência jurídica. O ius gentium não poderia ficar excluído desta duplicidade originária ${ }^{139}$. É possível aventar que, no caso desse último, a ambiguidade foi escancarada pelo fato de ter sido mencionado na Suma Teológica, enquanto que outros direitos não precisaram comparecer ${ }^{140}$.

\subsection{Michel Villey}

Vale mencionar, enfim, a concepção de Michel Villey, para quem o ius gentium foi concebido por Tomás de Aquino como essencialmente ligado ao direito natural ${ }^{141}$. Porém, à diferença de Santiago Ramírez, Villey se esmera em diferenciar direito natural de lei natural. Para ele, o direito das gentes se prende ao primeiro, consistindo no modo de encontrá-lo mediante auxílio

\section{$137 \quad$ ST I-II q. 95 a. $4 c$.}

138 SCHILLING, Otto. Das Völkerrecht nach Thomas von Aquin. Freiburg im Breisgau: Herdersche Verlagshandlung, 1919, pags. 28-29.

139 HERRERA, Daniel Alejandro. Ius gentium: ¿derecho natural o positivo? In: ZORROZA, Maria Idoya (org.). Proyecciones sistemáticas e históricas de la teoría suareciana de la ley: Jornadas de Iustitia et Iure en el Siglo de Oro. Buenos Aires, 2008, pag. 56.

140 "As leis se escrevem para declarar um e outro direito [i.e. o natural e o positivo]; mas de maneira diferente nos dois casos. A lei escrita contém o direito natural, mas não o institui, pois este não tira sua força da lei, mas da natureza. Quanto ao direito positivo, a lei escrita o contém e o institui, conferindo-lhe a força da autoridade." ST II-II q. 60 a. 5 c.

141 "Le jus gentium est vis-à-vis du droit naturel, tout à la fois le même et l'autre; il en est une sorte d'effluve, de réfraction dans nos consciences; une image approximative." VILLEY, Michel. Considérations intempestives sur le droit des gens. In: Archives de philosophie du droit, v. 32: le droit international (1987), pag. 19. da razão humana, estabelecendo sobre os bens um conhecimento discursivo e tateante ${ }^{142}$. Trata-se da determinação da utilidade de certos institutos a partir da resolução de casos particulares pelo juiz. A universalidade do direito das gentes nessa interpretação está em que as soluções dadas aos casos concretos serão replicadas ou fixadas em máximas jurídicas. Tais lugares comuns da arte jurídica poderão ser replicados em outras sociedades, disseminando-se pelo estudo do direito, a exemplo da atividade do pretor peregrino em Roma, encarregado de transladar as soluções da jurisprudência romana aos processos dos estrangeiros. Villey também chama a atenção para o caráter não estatal desse ius gentium, que era empregado pelos encarregados da solução dos litígios sem um mandado específico do imperador para tal, mas apenas em virtude da maior conveniência que as respostas encontradas em Roma poderiam ter para os litígios envolvendo os peregrini ${ }^{143}$. Ou seja, para o autor francês, o direito das gentes é mutável na medida em que as necessidades da comunidade humana se modificam, levando o juiz a tirar soluções novas do direito natural. E é um direito comum, na medida em que uma solução jurídica a um problema básico pode ser replicada por outros povos, ao menos em suas características primárias (no seu modo de raciocinar, pode-se dizer), respeitando as particularidades do direito positivo de cada sociedade. Embora Villey não empregue essa expressão, é possível qualificar seu direito das gentes de potencialmente universal, pois é passível de expansão e adoção por outras sociedades. Como o autor francês parece reconhecer, implicitamente, ao mencionar como exemplo o ius commune medieval ${ }^{144}$ — que serviu muito bem à Europa Ocidental, mas que, de forma alguma, ganhou amplitude universal — o ius gentium não incide igualmente sobre todos os povos do mundo, mas pode vir a ser progressivamente incorporado pelas sociedades cujo modo de vida seja compatível com os institutos "das gentes".

Enquanto para Ramírez, como visto, o direito das gentes consistia no resultado da mera aplicação da ra-

142 VILLEY, Michel. Considérations intempestives sur le droit des gens. In: Archives de philosophie du droit, v. 32: le droit international (1987), pag. 19.

143 VILLEY, Michel. Considérations intempestives sur le droit des gens. In: Archives de philosophie du droit, v. 32: le droit international (1987), pag. 20.

144 VILLEY, Michel. Considérations intempestives sur le droit des gens. In: Archives de philosophie du droit, v. 32: le droit international (1987), pag. 20. 
zão humana iluminada pela lei natural à realidade, para Villey o ius gentium decorre de um lento processo de idas e vindas através do qual os habitantes das sociedades concordam em adotar determinados institutos ou padrões para a solução de seus conflitos. Ramírez enxerga o direito das gentes em uma ótica linear, na qual as únicas variações se devem à imperfeição da razão humana, e um contínuo melhoramento deste direito mediante uma maior compreensão da lei natural é esperada. Michel Villey, por sua parte, admite que o ius gentium é fruto de um esforço de conhecimento, porém não da lei natural abstrata, e sim do direito natural, ou seja, de uma proporção entre homens e coisas que deve ser respeitada nos casos concretos. Ao resolver diversos casos, os jurisconsultos e pretores romanos perceberiam, segundo este autor francês, que certos padrões e medidas envolvendo pessoas e bens se repetiriam, e concluiriam tratar-se de uma exigência de direito natural. O ius gentium corresponderia à situação determinada em que se percebeu um tal padrão: nos exemplos do Aquinate, seriam de ius gentium a compra e venda, a ocupação das terras, a servidão. ${ }^{145}$

A contribuição de Michel Villey revela-se sobremodo relevante para uma compreensão mais acabada do modo em que o direito das gentes é encontrado. Sua tese da importância da atividade jurídica "cotidiana" mostra como o ius gentium se vincula às características de cada sociedade, e como se trata de um verdadeiro iustum, não de uma moral universal, reservada por Tomás à justiça geral. Por meio da elaboração de regulae jurídicas no âmbito da resolução dos litígios, institutos jurídicos são desenvolvidos e mantidos ${ }^{146}$, podendo ser exportados para outras comunidades se corresponderem às necessidades básicas destas, exercendo a função de instituições civilizadoras apontada por James Schall

145 "Le jus gentium n'est pas institué. [...] Il est ce qu'ont cru percevoir du droit naturel les juristes, à coup d'enquêtes, de controverses, de raisonnements faillibles. Mais son avantage est de couvrir cette fois un três large secteur de l'ordre des sociétés humaines: le partage des terres, les rapports entre commerçants, la vente, le louage, etc.... Bien entendu dans chaque cité, le droit positif, afin de subvenir aux insuffisances de cette besogne intellectuelle, $y$ adjoindra certaines précisions." VILLEY, Michel. Considérations intempestives sur le droit des gens. In: Archives de philosophie du droit, v. 32: le droit international (1987), pag. 19.

146 No mesmo sentido, Francesco Viola: "El derecho de gentes no es un ordenamiento jurídico completo y autónomo, sino que tiene que ver con un cuerpo de doctrinas, conceptos jurídicos, reglas y principios difusos, que se rehace y se reelabora continuamente, en consideración también a las progresivas exigencias de comunicación entre realidades diversas." VIOLA, Francesco. Derecho de gentes antiguo y contemporâneo. In: Persona y derecho 51 (2004), pag. 176. como diferencial do direito das gentes ${ }^{147}$. Pensa-se que essa formulação de Villey exprime, de outra maneira, o que se escreveu acima acerca das escolhas inconscientes que as sociedades fazem e que vão desenvolvendo o ius gentium.

\section{Considerações finais}

Da mesma forma que transita entre o direito natural e o positivo, foi possível verificar que o ius gentium de Tomás de Aquino se situa em um indefinido limite entre o mundo romano e a universalidade que será típica da modernidade. Enquanto as referências, o vocabulário, os exemplos e as categorias são romanas, com uma ou outra atualização medieval especialmente devida à obra de Isidoro de Sevilha, a formação, as fontes e o propósito do direito das gentes se enquadram perfeitamente na célebre síntese tomista entre o pensamento filosófico aristotélico e a visão de mundo unitária, totalizante e sem limites típica do Cristianismo ${ }^{148}$. O resultado é uma construção híbrida e tão flexível que parece desimportante para a realidade imediata na qual o autor da Suma vivia. Contudo, é sabido que as possibilidades latentes do ius gentium foram valorizadas e exploradas quando as condições históricas o pediram: foi assim que o dominicano espanhol Francisco de Vitoria, grande estudioso de Tomás e comentador dos tratados da Lei e da Justiça, liderou a Escolástica Espanhola no estudo dos graves problemas oriundos do descobrimento e colonização do Novo Mundo ${ }^{149}$.

147 SCHALL, James V. Natural Law and the Law of Nations: Some Theoretical Considerations. In: Fordham International Law Journal, vol. 15, n. 4, 1991, pag. 1024.

148 Alfred Verdross menciona o "grande pensamento universalista da Idade Média que inspirou todos os célebres fundadores dessa ciência [do Direito Internacional]...”. VERDROSS, Alfred. O fundamento do direito internacional. Revista de Direito Internacional, Brasília, v. 10, n. 2, 2013. Título original: Le fondement du droit international. Recueil des cours de l'Académie de Droit International, 1927, p. 325-384. Tradução de Marcelo Dias Varella (coordenador), Amábile Pierroti, Luiza Nogueira e Marlon Tomazette. Disponível em: < https://www.publicacoesacademicas.uniceub.br/rdi/article/ view/2685/pdf > . Acesso em: 01.09.2018, pag. 3 .

149 VITORIA, Francisco de. Relectiones: sobre os índios e sobre o poder civil. Tradução do latim de Paulo Sérgio de Vasconcellos. Org. e apresentação de José Carlos Brandi Aleixo. Brasília: Ed. Universidade de Brasília, 2016. Disponível em: < http:// funag. gov.br/loja/download/Relectiones-IPRI-05-04.pdf > . Acesso em: 27.12.2018. Para uma perspectiva do labor vitoriano no contexto da historiografia crítica do Direito Internacional, cf. GALINDO, George Rodrigo Bandeira. Para que serve a história do direito in- 
Dessa forma, é possível concluir pela afirmação da hipótese testada neste trabalho: o direito das gentes de Tomás de Aquino era, no sistema elaborado pelo mestre medieval, um conceito tão universalmente aplicável quanto suas noções de direito natural, direito positivo e lei natural. Trata-se da noção de uma adaptação gradual da exigência geral de igualdade no trato mútuo envolvendo bens às vicissitudes que cada sociedade enfrentará em seu cotidiano. Essa primeira adaptação é tão genérica que se repete em diversas comunidades (mas não em todas), variando, apenas, de acordo com grandes configurações histórico-geográficas que vão identificando cada nação. É certo que tal conceito ainda não tem nada que ver com o moderno Direito Internacional, por faltar-lhe a dimensão do relacionamento entre entidades soberanas. Porém, é igualmente verdade que o ius gentium tomista possibilita conceptualizar o Direito Internacional.

Vale considerar se a ideia de um direito de passagem entre o natural e o positivo não possui futuro ainda hoje no Direito Internacional. Os esquivos problemas da fundamentação, natureza, conteúdo e eventuais modificações do ius cogens seriam provavelmente respondidos pelo autor da Suma com uma referência a seu direito natural ${ }^{150}$. Já a dramática disputa sobre o conteúdo e a universalidade dos direitos humanos entre as grandes tradições jurídicas hodiernas se beneficiariam, quiçá, de sua inserção na categoria de um moderno ius gentium, com fundamento em certas regularidades antropológicas universalmente observáveis, e aplicação proporcional a depender das objetivas circunstâncias econômicas, geográficas, físicas etc. que identificam cada sociedade da moderna comunidade internacional.

\section{ReferênCIAS}

ALVES, José Carlos Moreira. Direito Romano, vol. I, $13^{\mathrm{a}}$ ed. Rio de Janeiro: Forense, 2003.

AQUINAS, Thomas. Commentary on Aristotle's Po-

ternacional? Revista de Direito Internacional, Brasília, v. 12, n. 1, 2015. Disponível em: < https://www.publicacoesacademicas. uniceub.br/rdi/article/view/3368/pdf >. Acesso em: 27.12.2018, pag. 344.

150 O jusfilósofo tomista John Finnis faz esta relação, cf. FINNIS, John. Direito natural em Tomás de Aquino. Sua reinserção no contexto do juspositivismo analítico. Trad. Leandro Cordioli. Porto Alegre: Sergio Antonio Fabris, 2007, pag. 94. litics. Versão para o inglês de Richard J. Regan. Indianapolis; Cambridge: Hackett, c2007.

AQUINO, Sancti Thomae de. Sententia libri Politicorum. Ed. Leonina, 1971. Disponível em: < http:// www.corpusthomisticum.org/cpo.html\#79140 >, acesso em: 01.09.2018.

AQUINO, Santo Tomás de. Da Justiça. (Título original: "Sententia libri Ethicorum, Liber 5".) Tradução de Tiago Tondinelli. Campinas: Vide Editorial, 2012.

AQUINO, Tomás de. Suma teológica, 9 vols. Tradução ao português pela equipe da ed. Loyola. São Paulo: Loyola, 2005.

ARISTÓTELES. Ética a Nicômaco. Tradução do grego de António de Castro Caeiro. São Paulo: Atlas, 2009.

AUBERT, Jean-Marie. Le droit romain dans l'oeuvre de Saint Thomas. Paris: J. Vrin, 1955.

AUGUSTINUS HIPPONENSIS (Santo Agostinho de Hipona). De civitate dei contra paganos libri XXII, Livro XIX, 15. Roma: Città Nuova Editrice, [?]. Disponível em: < http://www.augustinus.it/latino/index. htm >. Acesso em: 01.09.2018.

AZEVEDO, Luiz Henrique Cascelli de. Ius Gentium em Francisco de Vitoria: a fundamentação dos Direitos Humanos e do Direito Internacional na tradição tomista. Porto Alegre: Sergio Antonio Fabris, 2008.

BARRETTO, Rafael Zelesco. O caso hipotético da morte do embaixador francês na Espanha: duas espécies de ius gentium em Francisco de Vitoria. Revista de Direito Internacional, Brasília, v. 14, n. 2, 2017.

BASTIT, Michel. Nascimento da lei moderna: o pensamento da lei de Santo Tomás a Suarez. São Paulo: Martins Fontes, 2010.

BRIERLY, J.L. The Law of Nations: an Introduction to International Law, $5^{\text {a }}$ ed. New York: New York University Press, 1955.

CASTILLA URBANO, Francisco. Francisco de Vitoria. In: DAL RI JR., Arno; VELOSO, Paulo Potiara de Alcântara; LIMA, Lucas Carlos (orgs.). A Formação da Ciência do Direito Internacional. Ijuí: Ed. Unijuí, 2014.

CHROUST, Anton-Hermann. The 'Tus Gentium' in the Philosophy of Law of St. Thomas Aquinas. In: Notre Dame Law Review, vol. 17, n. 1 (1941). 
DRESCHER, Seymour; FINKELMAN, Paul. Slavery. In: FASSBENDER, Bardo; PETERS, Anne (orgs.). The Oxford Handbook of the History of International Law. Oxford: Oxford University Press, 2012.

ESTÉBANEZ, Emilio G. La virtud de la justicia. Introducción a las cuestiones 57 a 60. In: AQUINO, Santo Tomás de. Suma de Teología, tomo III. Madri: Biblioteca de Autores Cristianos, 1990.

FINNIS, John. Aquinas. Moral, Political, and Legal Theory. Oxford: Oxford University Press, 1998 (reimpr. 2004).

FINNIS, John. Direito natural em Tomás de Aquino. Sua reinserção no contexto do juspositivismo analítico. Trad. Leandro Cordioli. Porto Alegre: Sergio Antonio Fabris, 2007.

GALINDO, George Rodrigo Bandeira. Para que serve a história do direito internacional? Revista de Direito Internacional, Brasília, v. 12, n. 1, 2015. Disponível em: < https://www.publicacoesacademicas.uniceub.br/ rdi/article/view/3368/pdf > . Acesso em: 27.12.2018.

GILISSEN, John. Introdução histórica ao direito, $3^{\mathrm{a}}$ ed. Tradução de António Manuel Hespanha e Manuel Macaísta Malheiros. Lisboa: Calouste Gulbenkian, 2001.

GIORDANI, Mário Curtis. Iniciação ao direito romano, $2^{\mathrm{a}}$ ed. Rio de Janeiro: Lumen Juris, 1991.

GROSSI, Paolo. A ordem jurídica medieval. São Paulo: Martins Fontes, 2014.

HAGGENMACHER, Peter. Grotius et la doctrine de la guerre juste. 1983. Tese (Doutorado) - Institut Universitaire de Hautes Études Internationales, Genebra.

HERRERA, Daniel Alejandro. Ius gentium: ¿derecho natural o positivo? In: ZORROZA, Maria Idoya (org.). Proyecciones sistemáticas e históricas de la teoría suareciana de la ley: Jornadas de Iustitia et Iure en el Siglo de Oro. Buenos Aires, 2008.

HERRERA, Daniel Alejandro. Ius gentium: ¿derecho natural o positivo? In: ZORROZA, Maria Idoya (org.). Proyecciones sistemáticas e históricas de la teoría suareciana de la ley: Jornadas de Iustitia et Iure en el Siglo de Oro. Buenos Aires, 2008.

ISIDORO DE SEVILLA. Etimologías. Edición bilingüe. Versão ao espanhol de José Oroz Reta e ManuelA. Marcos Casquero. Madri: Biblioteca de Autores Cristianos, 2004, pag. 501. Disponível em: < http://www. larramendi.es $/ \mathrm{i} 18 \mathrm{n} /$ consulta $/$ registro.cmd?id $=5374>$. Acesso em: 01.09.2018.

JUSTINIANO I (org.). Digesto de Justiniano, livro I. Tradução de Hélcio Maciel França Madeira, $2^{a}$ ed. São Paulo: Revista dos Tribunais; Osasco: UNIFIEO, 2000.

KOSKENNIEMI, Martti. A History of International Law Histories. In: FASSBENDER, Bardo; PETERS, Anne (orgs.). The Oxford Handbook of the History of International Law. Oxford: Oxford University Press, 2012.

MACEDO, Paulo Emílio Vauthier Borges de. O mito de Francisco de Vitória: defensor dos direitos dos índios ou patriota espanhol? Revista de Direito Internacional, Brasília, v. 9, n. 1, p. 1-13, jan./jun. 2012. Disponível em: < https://www.publicacoesacademicas. uniceub.br/rdi/article/view/1602/1591 >. Acesso em: 27.12.2018.

MACEDO, Paulo Emílio Vauthier Borges de. Uma comparação entre os conceitos de Jus Gentium em Francisco Suárez e Hugo Grócio. 2007. Tese (Doutorado em direito) - Universidade do Estado do Rio de Janeiro, Rio de Janeiro, 2007.

MARKY, Thomas. Curso elementar de Direito Romano, $8^{a}$ ed. São Paulo: Saraiva, 2007.

MULDOON, James. Spiritual Freedom - Physical Slavery: The Medieval Church and Slavery. In: Ave Maria Law Review, vol. 3, Spring 2005.

NUSSBAUM, Arthur. The Significance of Roman Law in the History of International Law. In: University of Pennsylvania Law Review, vol. 100 (1952).

OLGIATI, Francesco. El concepto de juridicidad en Santo Tomás de Aquino. Pamplona: EUNSA, 1977.

ORTIZ TREVIÑO, Roberto Gerardo. La naturaleza jurídica del ius gentium de acuerdo con la doctrina de Francisco de Vitoria. Estudio breve en honor al pensamiento de Antonio Gómez Robledo. In: Anuario Mexicano de Historia del Derecho, vol. XVII.

OSUNA FERNÁNDEZ-LARGO, Antonio. Comentário à I-II q. 95 a. 4. In: AQUINO, Santo Tomás de. Suma de Teología, tomo II, $2^{a}$ ed. Madri: Biblioteca de Autores Cristianos, 1989

RAMÍREZ, Santiago Maria. El derecho de gentes o natural en Santo Tomás de Aquino (1225-1274). Editado por Carlos Rubén Terceiro-Muiños. San Luis: 
Universidad Católica de Cuyo, 2007.

RUSSELL, Frederick H. The Just War in the Middle Ages. Cambridge: Cambridge University Press, 1975.

SCHALL, James V. Natural Law and the Law of Nations: Some Theoretical Considerations. In: Fordham International Law Journal, vol. 15, n. 4, 1991.

SCHILLING, Otto. Das Völkerrecht nach Thomas von Aquin. Freiburg im Breisgau: Herdersche Verlagshandlung, 1919.

SCOTT, Samuel P. The Civil Law, vol. 2: Enactments of Justinian: Institutes, Digest (Pandects) Books I and II. Versão inglesa de Samuel P. Scott. Cincinatti: The Central Trust Company, 1932. Disponível em: < http://www.constitution.org/sps/sps02.htm >. Acesso em: 01.09.2018.

SHERMAN, Gordon E. Jus Gentium and International Law. In: The American Journal of International Law, vol. 12, n. 1 (jan. 1918).

SIMON, Yves R. The Tradition of Natural Law: A Philosopher's Reflections. Editado por Vukan Kuic. Nova York: Fordham University Press, 1992.

SORIA, Carlos. Introducción a las cuestiones 95-97. In: AQUINO, Santo Tomás de. Suma Teológica, tomo VI. Madrid: Biblioteca de Autores Cristianos, 1956.

TUORI, Kaius. The Reception of Ancient Legal Thought in Early Modern International Law. In: FASSBENDER, Bardo; PETERS, Anne (orgs.). The Oxford Handbook of the History of International Law. Oxford: Oxford University Press, 2012.

URDÁNOZ, Teofilo. Introducción a la cuestión 57. In: AQUINO, Santo Tomás de. Suma Teológica, tomo VIII. Madrid: Biblioteca de Autores Cristianos, 1956.
VERDROSS, Alfred. O fundamento do direito internacional. Revista de Direito Internacional, Brasília, v. 10, n. 2, 2013, pag. 2. Título original: Le fondement du droit international. Recueil des cours de l'Académie de Droit International, 1927, p. 325-384. Tradução de Marcelo Dias Varella (coordenador), Amábile Pierroti, Luiza Nogueira e Marlon Tomazette. Disponível em: < https://www.publicacoesacademicas.uniceub.br/rdi/ article/view/2685/pdf >. Acesso em: 10.07.2017.

VILLEY, Michel. A formação do pensamento jurídico moderno. São Paulo: Martins Fontes, 2005.

VILLEY, Michel. Considérations intempestives sur le droit des gens. In: Archives de philosophie du droit, v. 32: le droit international (1987).

VILLEY, Michel. Direito Romano. Porto: Res, 1991.

VILLEY, Michel. Questões de Tomás de Aquino sobre direito e política. São Paulo: Martins Fontes, 2014.

VIOLA, Francesco. Derecho de gentes antiguo y contemporâneo. In: Persona y derecho 51 (2004).

VITORIA, Francisco de. Relectiones: sobre os índios e sobre o poder civil. Tradução do latim de Paulo Sérgio de Vasconcellos. Org. e apresentação de José Carlos Brandi Aleixo. Brasília: Ed. Universidade de Brasília, 2016. Disponível em: < http://funag.gov.br/loja/ download/Relectiones-IPRI-05-04.pdf > . Acesso em: 27.12.2018.

WILLIAMS JR., Robert A. The Medieval and Renaissance Originis of the Status of the American Indian in Western Legal Thought. In: Southern California Law Review, n. 57 (1983). 
Para publicar na Revista de Direito Internacional, acesse o endereço eletrônico www.rdi.uniceub.br ou www.brazilianjournal.org.

Observe as normas de publicação, para facilitar e agilizar o trabalho de edição. 